University of Rhode Island

DigitalCommons@URI

Open Access Dissertations

1963

\title{
The Interrelationships Between Chronic Restraint Stress and Reserpine Sedation: Effects on Pituitary-Adrenal Function and Brain Serotonin and Norepinephrine Levels in Male Albino Rats
}

John Adam Rosecrans

University of Rhode Island

Follow this and additional works at: https://digitalcommons.uri.edu/oa_diss

\section{Recommended Citation}

Rosecrans, John Adam, "The Interrelationships Between Chronic Restraint Stress and Reserpine Sedation: Effects on Pituitary-Adrenal Function and Brain Serotonin and Norepinephrine Levels in Male Albino Rats" (1963). Open Access Dissertations. Paper 163.

https://digitalcommons.uri.edu/oa_diss/163

This Dissertation is brought to you for free and open access by DigitalCommons@URI. It has been accepted for inclusion in Open Access Dissertations by an authorized administrator of DigitalCommons@URI. For more information, please contact digitalcommons-group@uri.edu. 
THE INTERRELATIONSHIPS BETWEEN CHRON IC RESTRA INT STRESS AND RESERPINE SEDATION: EFFECTS ON PITUITARY-ADRENAL FUNCTION AND BRAIN SEROTONIN AND NOREPINEPHRINE LEVELS IN MALE ALBINO RATS BY JOHN ADAM ROSECRANS

A THESIS IN PARTIAL FULFILLMENT OF REGUIREMENTS FOR THE DEGREE OF DOCTOR OF PHIIOSOPHY IN PHARMACEUTICAL SCIENCE (Pharmacology) 
DOCTOR OF PHILOSOPHY THES IS

OF

JOHN ADAM ROSECRANS

\section{Approved:}

Thes ls committee:

Cha Irman

Dean of Graduate Studies

UN IVERS ITY OF RHODE ISLAND

1963

11 


\section{ACKNOWTEDGMENT}

The author wishes to express his appreciation to Dr. John J. De Feo for his continued encouragement and patience throughout this invegtigation.

He is furtber indebted to the other members of the graduate committee, Dr. R. Harrison, Dr. J. Purvis and Dr. C. I. Smith, for their valuable suggestions throughout this investigation. The author is also grateful to the National Institutes of Mental Health for a predoctoral fellowship (MH-10,570 Cl) which made this investigation possible. The author would also like to acknowledge the tolls of his wife, Norma, during the preparation of this dissertation. 


\section{ABSTRACT}

The General Adaptation Syndrome (G.A.S.) was characterlzed for chronic forced restraint stress in normal and reserpinized (I mg/kg, I.P.) male albino rats. This was accomplished by analyzing the interrelationships among brain neurohumoral levels (serotonin (5-HT) and norepinephrine (NE)), serum corticosterone (KS) levels, and various organ welghts such as thymu, testes, pitultarles, and adrenals.

Reserpine was observed to prevent normal rats from adapting to this stress (mortality rate was 50\%) possibly via inanition. It was suggested that the overall non-adaptive effects produced could ultimately be due to the ablilty of reserpine to Induce a chemical sympathectomy. Thus, by depleting the A.N.S. of accessible $\mathrm{NE}$, an animal would be unable to respond to a severe change in environment.

Control animals demonstrated both behavioral and neurochemical adaptation in response to this stress. Initial excitation assoclated with restraint was related to increased brain 5-HT levels and decreased brain NE levels. As the experiment progressed, stress animals became less excltable and easler to handle which was also assoclated with the return of both brain amines to normal levels.

In contrast, reserpinized anlmals subjected to chronic restraint stress became progressively more exc1table and difficult to handle as the experiment proceeded. This behavior can 
best be described by C.N.S. depression associated with extreme bypersensitivity to handing. This progressive change in behavior was correlated with the progressive depletion of brain NE levels, since brain 5w remalned at relatively normal levels. The progressive incroase in exc1tation thus appeared to be dopendent on NE depletion or release.

Reserplne ( $1 \mathrm{mg} / \mathrm{kg}$, I.P.) Induced a prugressive depletion of brain NE while it did not do so w1th 5-HT. This was 1nterpreted as indicating that 5 HT synthesis was equivalent to its reloase. In contrast $0.5 \mathrm{mg} / \mathrm{kg}$, I.P., of roserpino was found to produce a progressive depletion of $5-H T$ as well as NE. On the other hand, higher doses of reserpine inhlbited the serotonin depletion effects produced by the $1 \mathrm{mg} / \mathrm{kg}$. In fact, some animals demonstrated levels above normal following the chronlo administration of reserpline (2 mg/kg, I.P.). Therefore, a possible serotonin-feedback mechanism involving the freo and bound concentrations of this amine may be indicated.

Increased brain 5-HT levels twenty-four hours af ter the thirty-geoond dose of reserpine was al so suggestive of an 1ncreased synthes is rate. Behavioral excltablitty was also found to characterize these increased serotonin levels in all experiments conducted. Norepinephrine, on the other hand, di not demonstrate any observable changes in the rate of synthesis under the influence of reserpine. 
TABLE OF CONTENTS

Page

ACKNOWLEDGMENT . . . . . . . . . . . . . 111

ABSTRACT . . . . . . . . . . . . . . . . IV

LIST OF TABLES . . . . . . . . . . . . . v V11

LIST OF FIGURES . . . . . . . . . . . . . . . . $\mathrm{x}$

LIST OF ABBREVIATIONS . . . . . . . . . . . . . xi

I. INTRODUCTION ................. 1

II. REVIEW OF THE LITERATURE . . . . . . . . . 3

Adaptation The Pltultary-Árenal Axis : : : : : : 4

The General Adapt1ve Syndrome . . . . 7

The Mode of Action of Reserpine . . . . 10

1. Electrophys lologlcal Mechanisms. . 10

2. Neurochem1cal Mechanisms . . . 11

Effects of Reserpine on the P1tuitary-

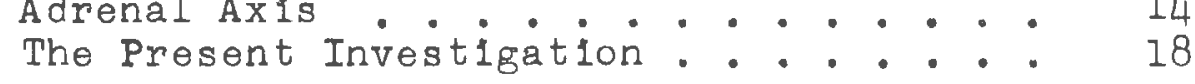

III. EXPERIMENTAL . . . . . . . . . . . . 22

General
Design of Experiments: : : : : : : : : : 22

1. Single and Repeated Dose Recovery

2. Effects of Chronlc Restraint Streas in Normal and Reserpinlzed Male

Albino Rats......... . 24

3. Effects of Single and Repeated

Graded Doses in Normal Male Albino

Rats ............. 25

Sacrifice, Removal and Preservation of

Tissues . . . . . . . . . . . ch

Organ Weight Data: : : : : : : : : : c7

Chem1cal Assays . . . . . . . . . 27

1. Serum Corticosterone . . . . . 27

2. Brain Serotorin (5-HT) and Norepine-
phrine (NE) . . . . . . 28 
Control Data .......... 29

IV. RESULTS AND DISCUSSION . . . . . . . . 31

Single and Repeated Dose Recovery Exper1ments with Reserpine . . . . . . . . Effects of Reserpine in Animals Subjected to Dally Forced Restraint stress .... Effects of Single and Repeated Graded Doses of Reserpine in Normal Albino Rats. 64

V. GENERAL DISCUSSION . . . . . . . 74

VI. SUMMARY AND CONCLUSTONS . . . . . . 85

vII. LITERATURE CITED . . . . . . . . . . . 87 


\section{LIST OF TABLES}

Table

I. The Recovery of Pituitary-Adrenal Function and Brain Norepinephrine and Serotonin

Levels Following A Single Dose of Reserpine in Male Albino Ratsa . . . . . . . . .

II. The Recovery of Pituitary-Adrenal Functior. and Brain Norepinephrine and Serotonin Levels Following Repeated Da1ly Doses of Reserpine (32 days)a . . . . . . . . 34

IIA. A Comparison of the Effects of Reserpine on Brain NE and 5-HT Levels Obtained from Different Experiments . . . . . . . . . .

III. Effects of Chronic Regtraint Stress on the Food and Water Balance and Mortality Rate of Normal and Reserpinized Male Albino Rats $(32 \text { days })^{a}$................... 4 E

IV. Effects of Chronic Restraint on the Thymas Welghts of Normal and Reserpinizec Male Albino Ratsa . . . . . . . . . . . 43

V. Fffects of Curonic Restraint Stress on the Testes Welghts of Normal and Reserpinized Male Albino Ratsa . . . . . . . . . 44

VI. Effects of Chronic Restraint on the wet Adrenal Welghts of Normal and Reserpinized Male Albino Rats ${ }^{a}$............ . 45

VII. Effects of Chronic Restraint Stress on the Dry Adrenal Weights of Normal and Reserpin1zed Male Albino Ratsa . . . . . . . . 47

VIII. Effects of Chronic Restraint on the \% Adrenal Dry Welghts (ADW) of Normal and Reserpinized Male Albino Rats ${ }^{a}$. . . . . . 48

IX. Effects of Chronic Restraint stress on the Pituitary Welghts of Normal and Reserpinizod Male Albino Ratga ..............

X. Effects of Chronic Restraint Stress on the Serum Corticosterone Levels (KS) of Normal and Reserpinized Male Albino Ratsa ..... 
XI. Effects of Chronic Restraint Stress on Braln Serotonin (5-HT) Levels of Normal and Reserplnized Male Albino Rats ${ }^{\mathrm{a}}$. . . 52

XII. Effects of Chronic Restraint Stress on the Brain Norepinephrine (NF) Levels of Normal and Reserpinized Male Albino Ratsa. .

XIII. Effects of Single Graded Doses of Reserpine on P1tultary-Adrenal Function in Normal Albino Rats . . . . . . .

XIV. Eiffects of Repeated Graded Ioses of Reserplne (32 days) on P1tuitary-Adrenal Function in Normal Male Albino Rats ...

XV. Effects of Single and Repeated Graded Doses of Reserpine on Brain Serotonin and Norepinephrine Levels of Normal Male Albino Rats . . . . . . . . . . 


\section{LIST OF FIGTRES}

Figure

Page

1. A theoret1cal representation of the hypothalamico-adenohypophyseal-adrenocortical axis and drug action ...........

2. The relationship betwoer pitultaryadrenocortical responses and brain neurohumoral changes following a single dose of reserpine $(1 \mathrm{mg} / \mathrm{kg}$, I.P.) . . . . . . . . .

3. Pitilary-adrenocortical and brain neurohumoral recovery following thirty-two doses of reserpine (1 mg/kg, I.P.) . . . .

4. A comparison of the effects of chronic restraint stress on various organ weight changes of normal and reserpinized male

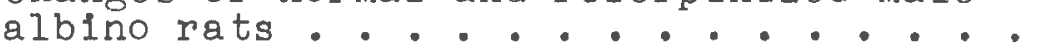

5. A comparison of the effect of chronic restraint stress on pitultary-adrenocortical function of normal and reserpinized male albino rats... . . . . . . . . .

6. A comparison of the effects of chronic restraint stress on corticosterone levels and brain neurohumoral levels . . . . . .

7. Effects of single graded doses on pitultary-adrenocortical function in normal male albino rats . . . . . . . . . .

8. Effects of single and chronic graded doses of reserpine on brain serotinin (5-HT) levels of normal male albino ruts. 
A BTREVIATIONS ${ }^{a}$

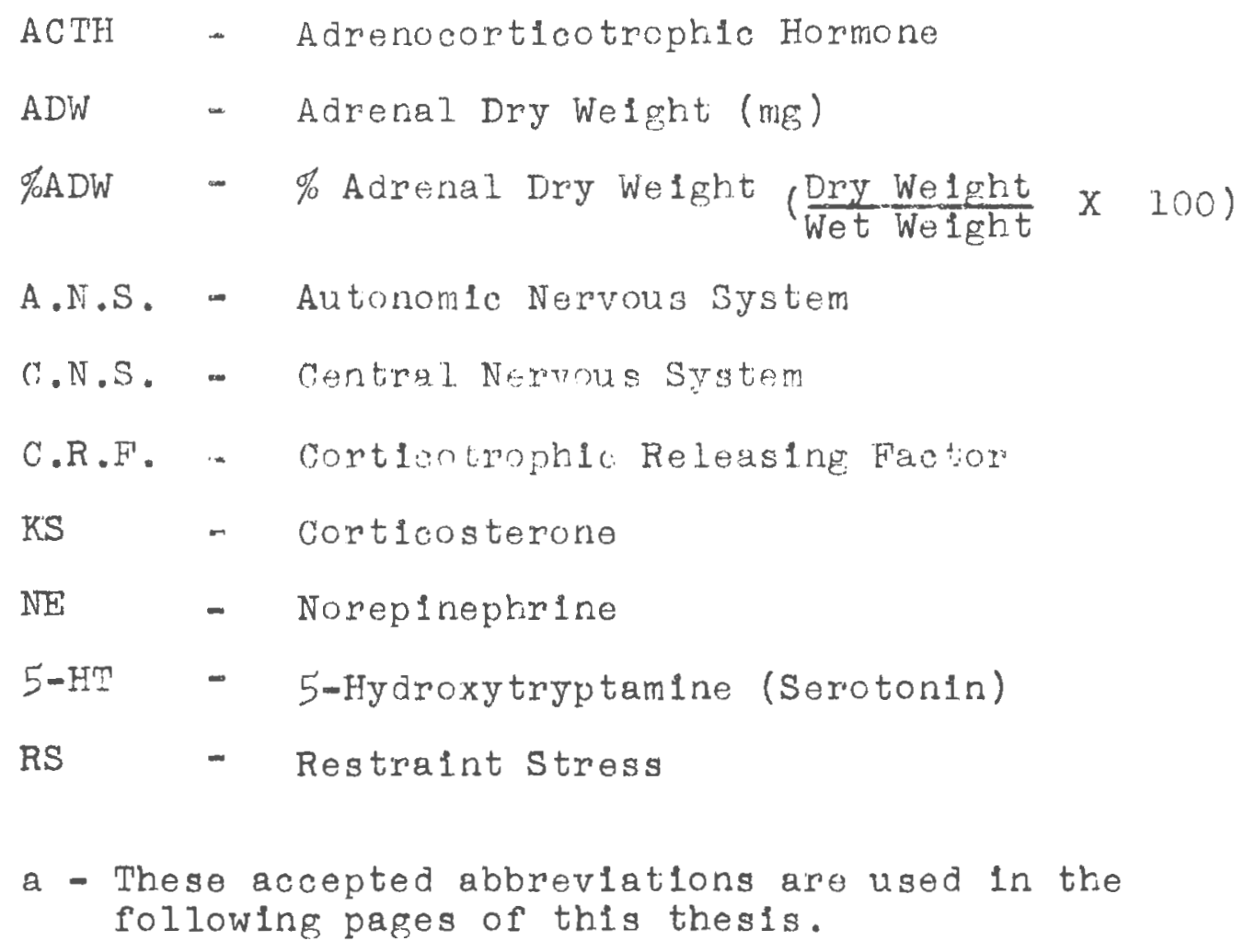




\section{INTRODUCTION}

The ability of an animal to adapt to both internal and external. changes in environment has been known to be essential to life since Claude Bernard's discussions on the "Internal Mil leu". Modern research in this fleld has amassed evidence which clearly indicates that adaptation to changes of anvironmerit or to a strossor involyes an inter. play between the central and autonomic nervors systems and the endocrines, especially the pitultary-adrenal axis. The fact that adaptation involves nervous activity has led to studies of the effects of varlous drugs acting on the central nervous system on these interrelationships.

Tranquilizers such as reserpine have been especially studied because their sedative effects indicate an inhibition of the pituitary-adrenal axis. However, mach to the surprise of previous investigators, reserpine produced elther depression or stimulation of the pitultary-adrenal axis in response to acute stressors. These investigators studied reserpine in animals subjected to various stressors, but due to great variation in methodology and experimental design, divergent views of the effects of reserpine resulted.

To reconcile this state of apparent confusion recent investigators have presented strong evidence indicating that reserpine stimlates pituitary-adrenocortical function and does not inhibit stress acutely. Although this work is well 
documented, little consideration of the chronic effects of reserpine in stressed animals has been observed. A few isolated experiments on the effects of the chronic administration of reserpine in normal animals have not resulted in conclusive statements as to specific pitultary-adrenal interactions. Along with this, little thought has been given to the study of the chronic effects of reserpine on 1 ts proposed central nervous system mediators of tranqullization, norepinephrine (NE) and serotonin $(5-H T)$.

In view of trese inadequacies, this Investigation was deslgned to study of chronic effects of reserpine on the pitultary-adrenal axis and its proposed C.N.S. mediators of tranquilization. It has been the prime purpose of this investigation to study the interrelationships of the pituitaryadrenal axis and the brain neurohumoral agents NE and 5-HT with the behavioral sequences observed during chronic reserpine treatment in unstressed and chronically stressed rats. The significance of this research will reside in its ability to clarify the mode of action of reserpine in view of attemptIng to correlate these data with human pharmacology. 


\section{REVIEW OF THE LITERATURE}

\section{Adaptation}

The problem of animal adaptation has interested biologists for some time and has now become of interest to the pharmacologist since it has been realized that any drug could be considered a stressor to which an animal should adapt. Claude Bernard was first to recognize the necessity to maintain an internal constancy under any environmental change. Other investigators, including Frederica, Pfluger, and Richet (Cannon, 1932) were also quick to reallze that in order to carry out such equilibrations under environmental changes, an animal must possess some regulatory mechanism which could quickly and efficlently meet these provocative insults.

W. B. Cannon in attempting to solve this problem suggested that the autonomic nervous system (ANS) is the initiator of adaptive mechanisms. He also recognized the remarkable ability of an animal to maintain a varying internal environment within limitations so as to hold a relative constancy. This he termed Homeostasis. Cannon wrote:

\footnotetext{
"Here then is a striking phenomenon. Organisms composed of material which is characterized by the utmost inconstancy and unsteadiness, have somehow learned the methods of maintaining constancy and keeping steady in the presence of corditions which reasonably might be expected to prove profoundly disturbing."
} 
Cannon proposed that under environmental changes, A.N.S. stimulation, and especially plasma adrenalin, could initiate cellular preparadness, and therefore, permit adaptation. His main methodological approach was total or partial sympathectomy. Homeostatic responses were then observed under normal and stress conditions. To better appreciate his conclusions a passage from his monograph on Homeostasis has been cited:

"If sympathectomized animals were set free
In the outer world and had to meet its
demands in struggle for food, safety and
warmth, they could be found more or less
defective according to the variable effi-
clency of their accessory stabilizing
mechanisms. Even in the most favorable
conditions displayed by the symattectom-
ized dog, however, absense of sympathetic
control of corrective devices is accompa-
nied by an inability to preserve constancy
of the internal environment though the
stress is only moderate."

Not being satisfled with Cannon's theories, Han Selye (1950) began a long series of experiments demonstrating that any animal presented with a noxious stressor responds in a very characteristic pattern elicited by adrenocortical hyperfunction via anterior pituitary stimulation. Because of the impact of his research on modern thinking concerning homeostatic mechanisms, his major postulates are now outIined:

I. When an animal is presented with some drastic change of elther its internal or external environment, the pituitary-adrenal axis is stim- 
ulated, eliciting an increase in plasma corticosteroids. These sterolds are believed to be the substances enabling an animal to adapt to these changes.

II. With prolonged stress a complete adaptive syndrome can be characterized, known as the General Adaptation Syndrome (G.A.S.).

III. The adaptive trigger, the anteriory pituitary, is essentially controlled by the hypothalamus. IV. There is no essential qualitative difference in the responses to different chronic stresses. The differences are basically quantitative.

Cannon's and Selye's theories do not conflict but tend to expose the tmue overall picture. Cannon worked on the adrenal medulla whereas selye studied the adrenal cortex. i'here is now little dcubt of the central position of the pituitary-adrenal axis in adaptation, but A.N.S. activity is assuredly not without importance. George sayers (1950) has compared these relationships in mach clearer a fashion. He states that the adrenocortical hormones play a general supportive role rather then an initiating role in bodily processes; whereas the adrenal medulla initiates cellular and metabolic changes in response to an emergency. The adrenal cortex plajs a passive role and makes it possible for various regulatory systems to expend the additional effort necessary for homeostatic adjustment. 
The Pituitary-Adrenal Axis

The relationship between adrenocortical activity and the pituitary was first demonstrated by Smith (I927). By extirpatirg the pitultary of the rat, he was able to demonstrate a rapid adrenocortical atrophy due to hypophysectomy. Since this classic investigation, rumerous sterold hormones have been isolated and identified as either secretory or biosynthetic precurser substancss cf the adrenal cortex. The release of these hormones into the general circulation has been found to be dependent upon the elaboration of a hormone released by the pituitary, the adrenocorticotrophic hormone (ACTH) (Vogt, 1960). It has further been observed that numerous types of stimuli (stressors) including chemlcal, physiological and psychological, induce ACTH release, thus producing a secondary release of the adrenocortical hormones.

Recently it has also been demonstrated that in addition to a negative feedback effect of plasma corticosteroids on the pituitary, ACTH is also regulated by higher centers of the C.N.S., particularly the hypothalamus (Harris, 1955). However, another mediator substance has been postulated as being responsible for ACTH release during stress situations. This second mediator has been postulated since there are no direct nervous connections between the hypothalamus and anterior pitultary. Saftaran (1962) has accumlated evidence supporting this view through the extraction and partial 
purification of a hypothalamic factor which will induce ACTH release from the pituitary in vitro. The General Adaptive Syndrome

As mentioned previously, Hans Selye has characterized a syndrome of chronic animal adaptation (1950). Selye has conclusively demonstrated the dependence of this syndrome on the pituitary-adrenocortical function through the classical methods of endocrinology of extirpation and replacement experiments. An animal which is presented with a chronic stressor, will undergo three distinct stages of change. An initial stage, or alarm reaction, a secondary stage of adaptation and finally a stage of exhaustion.

During the first stage, which may last from one to three days, physiological changes, such as lowered blood pressure, decreased body temperature, C.N.S. depression, and antidiuresis, are observed. During the second stage the stressor will be compensated for, and these physiological responses will return to normal or even increase. This second stage will continue until the animal can no longer adapt to or compensate for the stressor and the an 1mal will pass into the exhaustive stage and eventual death.

There are several organ welght changes which characterize each peculiar stage of this syndrome. In general, an increase in adrenal weight, a decrease of both the thymus and gonadal weights are indicated during the alarm reaction. During the latter stages of the syndrome similar changes will persist or return to normal. In terms of hormonal controls, these are 
assoclated with increased hormonal activity whereas a decreased organ welght is assoclated with decreased hormonal activi ty.

Throughout this syndrome several blochemlcal patterns also change indicating speciflc homeostatic adjustments. Changes in the blochemistry of the adrenal gland are ind1cative of Increased adrenal activity. Increases of adrenocorticosterold output and decreases in adrenal cholesterol and ascorblc acld have been found to be good indexes of adrenocortical hyperactivity. With in the past four years methods for the direct analysis of plasma and adrenal corticosterolds have also been developed (Gulllemin et al (1958). Th1s development has very greatly onhanced recent endocrinological and pharmacological investigations concerning the pltultary-adrenal axis.

Thus, as one can $s \theta \theta$, adaptation involves many homeostatic mechanisms. The sequence of events from the initiation of the adaptive trigger to the flinal release of adrenocortim cal hormones into the general clrculation, involves several chain reactions which are basically controlled through feedw back mechanisms. Therefore, theoretically a drug could elther stimiate or depress any one of these mechanisma and thus alter the end result. It should also be apparent that although adresocurtical autivity may be elther stimlated or inhiblted by a drug, this does not moan that this drug produces its offects via the C.N.S. alone. 


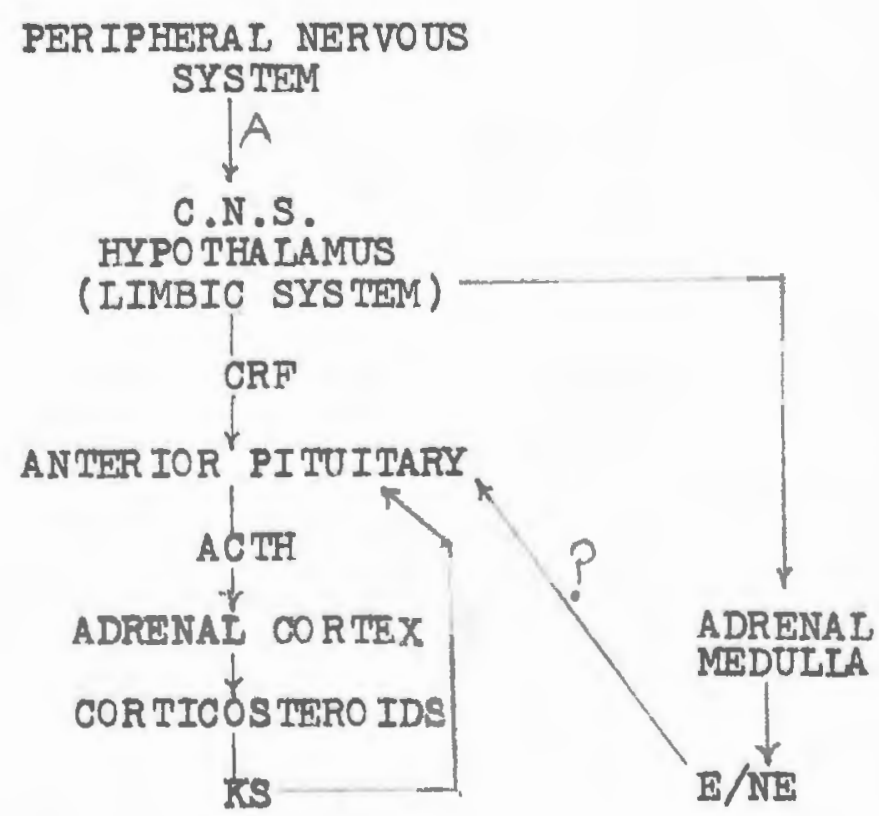

F1g. 1. A theoretical representation of the hypothalamicoadenohypophyseal-adrenocortioal axis and drug action?

\section{QPossible S1tes of Drug Action \\ (Inh1b1 tIon or stimi tion)}

1. Drugs oan inhiblt anj segment of the nervous segment (A-)

2. Drugs can act on any of the hormonal secretions CRF, ACTH, anu KS

They could affect any one of the following aspects of hormonal seoretlons:

1. Synthesis
2. Release
3. Site of action

F1g. I Is an attempt at presenting the possibilities of where a drug could attack the pitultary adrenel axis. As one can see there are more than a dozen ways of affecting this system and st1ll obtalning the same end result, elther stimulation or Inhlbition of corticosterold release. The most important point to be made here is the fact that some investigators after determining the effects of a drug on the adrenal 
corticosterold will then draw conclusions without examining drug effects on the intricate sequence of events outlined above.

The Mode of Action of Reserpine

Reserpine is a crystaline alkalold obtalned from the plant Rauwolfia serpentina (Schlittler et al, 1954). This drug has been known since the time of Arab and Greek physiclans and was used in Furope for many years in the treatment of varlous anxiety states. Due to technical difflculties, reserpine was not isolated nor characterized unt11 1952 (Mueller et al), when its sedative and hypotensive effects were also first exposed. Although aggressive anlmals such as monkeys could easily be handled after the administration of reserpine, the animals did not go to sleep and they could respond to al 1 external stimul1. This new type of sedative activity was defined as "tranquilization".

The mode of action of reserpine is one of the most interesting and challenging problems confronting current pharmacology. Because of its diffuse pharmacological effects, the mode of action of reserpine has escaped most investigators. This problem, however, is not peculiar to reserpine, for in dealing with drugs which affect the psyche, one has the overwhelming problem of attempting to evaluate changes in animal behavior.

1. Electrophys10logical Mechan1sms

The first pharmacological investigations of reserpine indicated that reserpine inhibited the hypothalams, initiating 
sympatholytic or parasympathomimetic effects (Plummer, 1954). Since these early investigations as to the effects of reserpine on brain electrophyslology, its effects have been observed to be increasingly more complex and diffuse. Depending upon the dose used, methods of electrical recording and stimulation, and on the specles of arimal used, one observes either facliltation or inhibition of many brain areas. Domino (1962) summarizes the effects of reserpine on various electrical systems of the brain by concluding that reserpine elther stimulates or depresses most areas of the brain, except for the Limbic system which it facllitates.

In studying the behavloral pattern of reserpine, Welskrantz (1957) otserved that reserpine appears to inhibit sensory input to the brain. Jacobsen (1959) further studied reserpine under psychic stress and found that it produced very nonspecific effects. He also stated that the general stupor produced by reserpine prevented the observation of possible specific effects.

The ma jor problem assoclated with the study of reserpine can be summar1zed best by Bein (1957). He states:

"Reserpine, which exhibits a complex pattern of
activity, differs frum other known substances
having central inhibiting activity, and its
mode of action is of a fundamentally new type."

2. Neurochemical Mechanisms

Current interest in the eflects of reserpine on brain neurohumoral agents was initiated by the observation that reserpine has the ability to reduce normal brain levels of Serotonin (5-HT), (Pletscher et al, 1956). Since reserpine curla not be detected In the brain during maximal sedation, Brodie and Shore 1957 
proceeded with the theory that it exerted its effects by releasing the normally bound 5-HT which would then be free to Inhlbit central synapses, thus producing tranquilization (1957).

Holzbauer and Vogt (1956) also found that reserpine depleted noreplnephrine (NE) from its normal brain stores and concluded that reserpine acted as a sympatholytic agent. Carlsson et al (1957) demonstrated that 3:4 dibydroxyphenylalanine (DOFA), one of the precursors of NE, restored the normal activity of reserpinized animals, presumably via the restoration ot depleted brain $\mathrm{NE}$. When a resorpinized animal was administered the precursor of 5-HT, 5-hydroxytryptophan, no change of activity occurred. Carisson (1958) has further demonstrated that reserpine depletes 3mydroxytyramine (dopamine), a precursor of NE which is now belleved to also possess a physlological role of its own. Therefore, Carlsson theorlzed that reserpine produces its effects by depriving central synapses of accessible NE and dopamine. (This is what Holzbauer and Vogt essentlally proposed.)

Paasonen (1961) alded Carlsson's theory by observing that raunescine, a rauwoltia alkalold, also produced sedation similar to reserpine, whloh selectively lowered NE to a greater degrea than 5-HT. He, however, ut1lized bloassay procedures for brain $\mathrm{NE}$ and 5-HT determinations as opposed to Brodie's fluorometric procedures. Pletscher et al (195\%) were also able to demonstrate differential ef'tects of various benzoquinolizine derivatives on these brain amiius. From these atuales they showed that the compound with the greater sedative effecta, also produced a greater depletion of $\mathrm{NE}$ than of $5 \mathrm{HT}$. 
Although evidence has heen presented contradicting Brodie's original postulates, he has been able to withstand these attacks with very convincing evidence that reserpine does produce its effects through 5-HT depletion. The present evidence supporting this theory is outlined as follows: (Brodie et al, 1961, Burns and Shore, 1961)

1. Reserpire causes equivalent depletion of both $N E$ and $5 \mathrm{wHT}$ from their normal bound states in the brain.

2. Brain lotels of reserplne cannot be detected at the onset of its sedative effects and depletion of both amines.

3. 5ubydroxytryptophan produces sedative effects similar to that of reserpine.

4. Reserpine appears to aftect the binaing of $5-\mathrm{HT}$ rather than its synthesis.

5. Alpha-Methyl-m-Tyrosine depletes the brain of 1 ts NE stores without demonstrating sedative effects.

6. Cold stress $\left(4^{\circ}\right)$ four hours prior to the administration of reserpine prevented its sedative effects. Similarily it also inhibited the depletion of 5-HT Induced by reserpine, but not that of $\mathrm{NE}$.

In a more recent paper, Revizin et al (1961) studying the effects of alpha-Methyl-m-Tyrosine, tetrabenazine and reserpine, demonstrated excellent correlation between CNS depression, evoked Iimbic potentials (reserpine usually causes facilitation, Domino, 1962), and lowered 5-HT levels. They could show no relationship between NE depletion and evoked potentials. This last investigation is extremely interesting and important 
in view of the fact that it is one of the few attempts at correlating CNS behavior with electrical and chemical events. It should also be pointed out that most of this work involves whole brains with little regard as to what occurs at the intracellular level. In an effort to overome this deficiency Giarma. and Schanberg (1050) and We1l-Malberbe et al (1961) studied sntrifuged brain fractions irom reserpinized animals. Giarman working with 5-HT and Weil-Malherbe working with NE found that reserpine increases the FREE/BOOND ratio of the concentrations of both amines. This ratio reters to the concentrations ot aminas of the cytoplasmic fraction to the concentrations of the amines in the particulate fraction. The signiflcarice of theso previous investigations points to the ability of reserpine to increase the concentrations of $\mathrm{NE}$ and 5-HT in the "Free" form. It is assumed that the "Free" form of either amine is that quantity accessabie to central synaptic sites.

Effects of Reserpine on the Pituitary-Adrenal Axis

Past research on the mechanism of the action of resurpine has emphasized the brain neurohumoral agents, $5-\mathrm{HT}$ ara NE. However, within the past two years, renewed interest in the effects of reserpine on the adrenal cortex has been noted. The endoerire aspocts of resarpine $(0.5 \mathrm{w} 1.0 \mathrm{mg} / \mathrm{kg})$ were Iirst studied by Guant et a I (195') in normal animals. From organ weight data, they concluded that reserpine was a mild stimulant of the adrenal cortex, while also possessing the ability to depress thymus and gonadal weights of male and fe- 
male albino rats. Accordingly, reserpine acted as a mild strijsor to which the organism was adapting.

Christian (1956) studied the chronic effects (three weeks) of reserpine (6.67 $\mathrm{mo} / \mathrm{ml}$ of drinking water) in mice living in isolation or crowding. Reserpine was found to inbibit the adrenal growth asscciated with each stress and was four 10 decrease fighting amongst mice subjected to chronic crowing. Some anlmals after two weeks of lsolation were suddenly placed in crowded quaters. Reserpine was fund to bave littie etiect on the environmental stress in mioe induced by the preceeding crange. It was conoluded that reserpine was akile to jnhinit the soclological corilicts with no apparent efeect on changes in environment.

In contrast welis et aI (1956) found reserplite to be a potent inhibitor of ACTH release in rats. Reserpine was adminIstered ( $2.5 \mathrm{mg} / \mathrm{kg}, \mathrm{I} . \mathrm{P})$ for flve days in order to adapt the animals to the drug. On the last day the arimals were subjected to either histamine or ether stress. Thene worker utilining the depletion of adrenal ascorbic acid (AAA) as an index of adrenocortical hypenfunction, demongtrated that reserpine was an inftial stimulator of stress, but after fire days, intibited these simerimposed stresses.

Guillemir (1457), while attempting to determine whether any of the proposed neurobumoral agents (Serotonin, Norepinephririe, Acetycholine and Histamine) were identical to the Corticotrophic Releasing Factor (CRF), did not agree with previous finalngs as to the ability of trarquilizers to inhibit acute stressors. In 
fact, he found that some of these dmags were themselves potent stressors (chlorpromazine and reserpine) although animals in this investigation were preinjected with the dmgs 7 days prior to the initiation of the stress. Guillemin's experiment differed from previous research in that it utilized a psychological stressor, forced restraint stress (holding an animal on its back for 90 min.). He observed that while reserpinized rats did not resist being restrained, the animal still displayed adrenocortical hyperfunction as indicated by the depletion of AAA.

The ability of reserpine to inhibit environmental stressors was again demonstrated by Mahouz and Ezz (1958). Utilizing continuous ether anesthesia with exsanguination, heat stress, and cold stress, they found that reserpine inbibited the usual depletion of AAA associated with these stressors. Since reserpine was not able to inhibit the usual depletion of AAA by various doses of ACTH, and reserpine did inhibit the above mentioned stressors, these workers concluded that reserpine inhibited the pituitary-adrenal axis by inhibiting some central regulatory mechanism, possibly the hypothalamus.

A novel theory of reserpine inhibition of ACTH release was reported by Kitay et al (1959). They contend that reserpine could cause depletion of ACTH, such that a stress followIng its administration would be unable to induce ACTH release, because of exhausted ACTH stores. Thus, a dmg could appear to inhibit the pituitary, but in essence, be actually stimulating it. This research has been extremely controversial, but 
might help explain previous divergent results concerning ding effects on the pltultary-adrenal axis.

Saffaran and Vogt, (1960), found that $2.5 \mathrm{mg} / \mathrm{kg}$ of reserpine (I.P.) caused ACTH release equivalent to that produced by the reserpine vebicle used in this experiment (the 1dent1cal vehiolo used in th is investigation). These workers studied the effects of reserpine on the pltultary directly by estimating the ACTH content of the pltultary, by in vitro methods. They further demonstrated that the depletion of ACTH by reserpine lasted only five days. Thus, they also concluded that at best reserpine affected the pltultary-adrenal axis as a nonspecifle stresgor.

Recently Montanar and Stockham (1962), have clarlfled to some degree prevlous conflicting reports. They have demonstrated that a $s 1 \mathrm{ngl} \theta 2.5 \mathrm{mg} / \mathrm{kg}$ dose of reserpine produces an Increase in the plasma corticosterone levels. After the admin1stration of this dose for four days, ether still produced adrenocortical hyperfunction (an increase of the plasma cort1costerone levels). Th1s find Ing, therefore, appears to contradict the predictions of Kitay et al (1959) and Malokel et al (1961).

In a series of interesting papers, Malckel, Westermann and Brodie (1962) have demonstrated excellent correlation between ACTH release and decreased brain serotonin levels. Malokel et al (1961) showed that roserpine was able to stinulate the pltultary-adrenal axis as evidenced by Increasod plasma cort1costerone levels. By studying these changes it was conoluded that reserpine $\left(5 \mathrm{mg} / \mathrm{kg}, I_{0} V_{0}\right)$ produced a persistent 
stimulation of ACTH for at least 20 hours. An equivalent effect was also observed during the exposure of rats to 20 hrs, of a cold stressor $\left(4^{\circ} \mathrm{C}.\right)$. A similar relationship between cold stress and reserpine was also demonstrated by the ir ability to deplete the pituitary of its normal stores of ACTH by at least $75 \%$. Westermann et al (1962) in their most recent publication again demonstrated the ability of reserpine to induce ACTH release, but with selective $\mathrm{NE}$ and $5-\mathrm{HT}$ depleters (alpha-MMT and various benzoquinolizine derlvatives) have presented excellent evidence indicating the dependence of ACTH release on brain serotonin. With the combined efforts of these workers and others (Revizin et al, 1961) they have presented a good case indicating the relation between Limbic stimulation via reserpine and ACTH release.

The Present Investigation

In reviewing the research concerning the mode of action of reserpine, the lack of correlation between different investigations at first may not be obvious unless one critically reads the papers cited here. The major difficulty in this research has been the inability of different investigators to agree on approaches and methods in which to study the mode of action of reserpine. This is especially true of investigations involving reserpine and its effects on the pituitary-adrenal axis.

It has been found very frustrating to observe different workers criticizing each other while at the same time they are studying reserpine in different systems. A good example of this is Montanari's (1962) statement that reserpine does not 
exhmat the pitultary ct its ACTH stores as a means of p1tu1tary irhikition of further stresses as proposed by Maickel. Malckel studied ACIH alrectly in the pltultary, whereas Montanari based his conclusions on adrenal and plasma corticosterone levels. He apparently overlooksd the fossibility that reserpine may also be acting directly on the adrenal cortex. A socond example of tris critlclsm lis the fact that different workere utilize difurent lasexes for deternining pitultaryadreral function when criticlzing each other as to whether reserpine stimulates or inhibits the pituitary adrenal axis, (adrenel ascorbic acid and plasma corticosterone). This polnt is of even more Importance since Montanari and Stockbam $(1062)$ have shown that AAA and plasma corticosterone do not always parellal each other in response to pltuitarywadrenal stimuiation.

A second criticism of previous research in this area is the apparent diagegard of basic pharmacological principles in studying the mechanism of action of reserpine. Throughout pharmacology' 3 short history, moh has been learned by studyIng the effects of chronic doses of dmas, especially in relation to the modes of action and side effects of drugs. In splte of this, present investigators refuse to study the effects of dmigs chronically in attempting to fortify their own theories as to mechanisma of action. In relation to this, few investigators have taken the time out to study the chronic effects of reserpine on brain neurohumeral levels or the pitultary-adrenal axis. 
It would seem loglcal to conclude that if reserpine acts by depleting normal brain 5-HT levels after one dose, It should also do so after thirty-two or even one hundred doses. Reserpire stimulation or inhibition of the pituitaryadrenal axis should also fall under the same analogy. If the thirtyasecond or one hundredth dose does not induce similar effects as the first dose, then either the drug does not act via this mechanlsm or the mechanism is being obscured by a secondary cause. Very few workers have utilized such an approach and because of this dismaying fact, the present investigation was initiated.

In view of these statements the following hypothesis concerning the relationship between chronic stress and reserpine sedation w111 be presented:

\section{Hyoothes is I}

If reserpine is either a speciflc stimulant or depressent of pitultary-adrenocortical hyperfunction in response to stress then these effects should be maintained throughout the duration of the present experiment.

\section{Hypothesis II}

If reserpine produces its sedative effects by releasing elther brain $\mathrm{NE}$ or $5 \mathrm{wT}$, then these effects should persist throughout the duration of the experiment.

\section{Hypothes is III}

If either of the above statements cannot be shown to be true, then elther reserpine does not act by these mechanisms, or a secondary effect is obscuring them. 
21

Since the first pages of this dessertation constant reference has been made to animal adaptation to environmental changes and the possible effects of orugs on various segments of these homeostatic me chanisms (Flg. 1). The above hypotheses make little mention of the se ideas but were certainly instrumental in their formulation.

Unfortunately many drugs which affect the C.N.S. are usually only studied in normal animals. This may appear irrelevant to this investigation, but when one considers that drugs are usually used in the treatment of diseased states rather than normal activity, this fact does have importance. It would also be important to know how drugs affect animal responses to environmental stressors, since many drugs are used for long periods of time in human therapeutics. This is especially true for reserpine.

Thus, aslde from attempting to learn more about the mode of action of reserpine, the importance of studying drug effects in chronically stressed animals from the view point of human pharmacology was also emphasized. 


\section{EXPHR IMENTAL}

Genera 1

Male albino rats $(150-220 \mathrm{~g})$ of the Sprague Dawley strain were used throughout this investigation. Reserpine was dissolved in a solution consisting of: $10 \%$ polyethylene glycol, $1 \%$ benzyl alcohol and $0.25 \%$ citric acld.

The following general procedures were conducted throughout this investigation except where otherwise stated:

1. Solutions of reserpine were prepared such that each dose was equivalent to $1 \mathrm{mI} / \mathrm{kg}$.

2. All animals serving as controls recelved $1 \mathrm{ml} / \mathrm{kg}$, I.P., of the reserpine vehicle.

3. In each individual experiment all aninals were administered either reserpine or its vehicle at 8:00 A.M.

4. Except where otherwise stated, all animals were sacriflced by decapitation 8 hours following the administration of reserpine or its vehic le.

5. All animals used in chronic experiments inftially welghed between 145 and 160 g. All other animals used weighed vetween 190 and $220 \mathrm{~g}$.

In order to determine the degree of sedation produced by reserpine three characteristic symptoms were utilized. These were: sedation, bleopharospasm or ptosis (eye closure) and

I Kindly supplied by Dr. R. Gaunt, Clba Pharmaceuticals, Inc., Summit, New Jersey 
diarrhea (Montanar1 and Stockham, 1962). In normal anjmals this syndrome was always observable indicating the inability of animals to develop tolerance to reserpine. Ptosis, however, was found to be of little quantltative value due to dally sukjective interpretations.

Design of Experiments

Due to the complex nature of this investigation, it was found necessary to perform three major interrelated experiments.

1. Single and Repeated Dose Recovery Experiments with Reserpine

This experiment was designed to determine the recovery of serum corticosterone (KS) and brain serotonin ( $5 \mathrm{mHT}$ ) and norepinephrine (NE) following one and thirty-two doses of reserpine ( $1 \mathrm{mg} / \mathrm{kg}$, I.P.) respectively. Thirty-two animals recelving a single dose of reserpine were sacriflced at either $4,8,12$, or 24 hours following its administration. Twentyfour animals serving as controls were also sacrificed at equivalent times.

Animals were preinjected with the reserpine vehicle $(1 \mathrm{ml} / \mathrm{kg}$, I.P.) every other day for 14 days to permit adaptation to both vehicle and injection procedure. Experiments were conducted on the 15th day.

Similar experiments were conducted followlng 32 doses of reserpine. Twenty-e1ght animals recelvinf: reserpine ( $1 \mathrm{mg} / \mathrm{kg}$, I.P.) dally were sacrificed at elther 8, 24, 80, or 154 hours following the last dose of reserplne. An equal number of animals serving as controls were also sacriflced. In this experiment animals were allowed food ad libltum. 
2. Effects of Chronic Restraint Stress in Normal and Reserpinized Male Albino Rats

This experiment was designed to test the previous hypotheses made. It was hoped that this experiment would ultima tely determine whether reserpine possessed any specific effects on the pituitary-adrenal axis.

One hundred and eighty animals initially weighing $145-160 \mathrm{~g}$ were used in the experiment. Animals in each experiment were divided into four experimental groups.

1 - CONTROL (These animals received $(1 \mathrm{ml} / \mathrm{kg}, I . P$.$) the$ reserpine vehicle dally)

2 - STRESS (Control animals + a daily forced restraint stress)

3 - CONTROL + RESERPINE (These animals recelved $1 \mathrm{mg} / \mathrm{kg}$, I.P. of reserpine daily)

4 - STRESS + RESERPINE (These animals recelved $1 \mathrm{mg} / \mathrm{kg}$, I.P. of reserpine dally + restraint stress daily)

Individual experiments of $1,6,12,18$, and 32 days were conducted. Stressed animals were subjected dally to a forced restraint stressor for a period of three hours by tying these animals on their backs to specially constructed boards (Renaud, 1959). Stress was initiated 5 hours after reserpine or its vehicle was administered to respective experimental groups. Animals were sacrificed immediately following release from re straint at the termination of the above mentioned experiments.

The animals of both stress groups were housed singly in standard metabolism cages constructed to isolate them from light stimuli while not under restraint. Control animals (unstressed) were housed in similar metabolism cages, two animals 
per cage; these anlmals were not 1solated from Ilght st1mul1. Urine volume, water and food intake were determined dally for all experimental groups in each experiment. Fach animal was allowed if g of purina rat ohow dally. This quantity of food was based on the average food intake for rata recelving chronic reserpine treatment (I mg/kg, I.P.).

3. Effects of S1ngle and Repeated Graded Doses of Reserpine in Normal Male 1 lbino Rats

This experiment was a second attempt at determining whether reserpine possesses any specific effects on the pltultary-adrenal axis. It was also utilized to clarify the interrelationships between reserpline sedation and brain 5-HT and NE levels. Single graded doses of reserpine, $0.5,1.0,2.5$, and 5.0 $\mathrm{mg} / \mathrm{kg}$, I.P., were administered to male albino rats (8 animals/ dose). Elght hours following adminiatration all animals were sacriflced. These animals were also preinjected with the rew serpine vehicle as in the first experiment levery other day for l' days).

A repeated graded dose experiment was also conducted using 64 male rats. These an $1 \mathrm{mals}$ were divided in to four groups. Three groups recelved diferent doses of reserpine $(0.5,1.0$, and $2.0 \mathrm{mg} / \mathrm{kg}, I . P$.$) ; the last group serving as control. AII$ anlmals were sacriflced 8 hours after the 32 nd dose of reser. pine. Doses of reserpine and 1ts vehicle were administered each day at $8: 00$ A.M.

In an attempt to separate rats whlch would be sensitive or resistant to reserpine, a special feeding and housing schedulc 
was utilized. This schedule was based on the premise that sensitive rats would eat less and thus, present a decreased rate of growth. This is a logical statement since the degree of reserpine-induced inanition is dependent on its dose (Gaunt et al, 1954). In relation to sensitive and normal reserpinized rats, resistant rats would be expected to eat more and present a greater rate of growth.

The schedule used is as follows:

1. Animals were allowed $18 \mathrm{~g}$ of food/animal for 10 days and were housed 20 animals/cage.

2. Animals were then subdivided by welght groups and placed in cages in groups of 10 animals/cage. Food was allowed ad libitum.

3. After 20 days of the experiment animals were again subdivided into three weight groups of $6-8$ aninals per group.

Sacriflce, Removal and Preservation of Tissue

Sacriflice was accomplished by decapltation with a manuy gaillotine ${ }^{1}$. Blood was collected in $12 \mathrm{ml}$ centrifupe tubos and allowed to stand for 8 to $16 \mathrm{hrs}$. in a cold room $\left(12^{\circ} \mathrm{C}\right)$. Blood samples were then centrifuged at 2,000 R.P.M., serum rem moved by decantation and stored at $-10^{\circ} \mathrm{C}$ until assay.

Brains were removed within two minutes after sacrifice and frozen immediately in test tubes immersed in a freezing mixture of solid carbon dioxide and trichlorethylene. The brains were later removed from the tubes and preserved in tin (Al) fol 1 at $-10^{\circ}$ unt 11 as $38 y$.

I Harvard Instrument Co. 
Organ We1ght Data

Following the removal of bralns, rat carcasses were placed in a cold room $\left(12^{\circ}\right)$ and were autopsied no later than 24 hrs after sacrifice. At autopsy, the adrenals, pitultaries, thymu and testes of each an 1 mal were removed, freed of fatty tissue, blotted and welghed to the nearest $0.1 \mathrm{mg}$ on a micro tissue balance.

After welghing, the adrenal glands were dried to a constant welght in an oven at $105^{\circ} \mathrm{C}$. In some instances pituitarles were alr dried in a desiccator and welghed (due to the small welght involved mean welghts were determined by pooling groups of pitultaries).

Chem1cal Assays

\section{Serum Cort1costerone (KS)}

In rats, the mafor adrenal corticosterold has been determined to be corticosterone (Zenker and Bernstein, 1958). KS levels were determined according to the spectrofluorometric method of Gulliemin et al (1959) in which corticosterone developes a fluorescent product in $84 \% \mathrm{H}_{2} \mathrm{SO}_{4}$. Fluorescence was read on an Aminco-Bowman Spectrof'luorometer ${ }^{1}$ at an activating wave length of $470 \mathrm{~m}$ and a fluorescent wave length of $510 \mathrm{mu}$ (photomultiplier tube = IP21). Standard curves (external gtandards) were prepared by running known amounts of corticosterone ${ }^{2}(0.2-1.0$ $\mathrm{ug} / \mathrm{ml}$ ) throuph the assay procedure. Recoveries from serum were $98 \pm 5 \%$ ( \pm S.D., $N=6$ ). Values were reported as ug/lon $\mathrm{ml}$. of serum.

I American Instrument co. In al l experiments utilizing this instrument assays were performed in quartz cuvettes utilizing an Xenon light source with a No. 5 slit arrangement.

2. Kindly supplied by Dr. G. C. Strayer, Schering Co., Bloomfleld, $N$. J. 
2. Brain Serotonin ( $5-\mathrm{HT})$ and Norep1nephrine (NE)

Brains were homogenlzed with $0.1 \mathrm{~N} \mathrm{HCl}$ in a Teflon Homogenizer and a 3-6 ml aliquot of the homogenate (300-400 $\mathrm{mg}$ of brain/ml) was taken for assay. Assays were usually performed on pooled samples ( $2-5$ brains/pool) except where indicated. Both amines were extracted with an NE butanol extraction procedure which has also been used to extract 5-HT (Mead and Finger, 1961). Serotonin was assajed by its natural fluorescence at an activating wave length $0: 292 \mathrm{mu}$ and a fluorescent wave length of 342 mu (photomultiplier tube $=$ IP28) in an Aminco-Bowman Spectrofluorometer. Brain NE was assayed by the development of fluorescence with potassium ferrlcyanide (Magnert and KIIngman, 1962). Its wave lengths for activation and fluorescence were respectively $475 \mathrm{mu}$ and $520 \mathrm{mu}$. It was also measured in an Aminco-Bowman Spectrofluorometer (photomultiplier tube $=$ IP21).

Standard curves (external standards) were prepared by running known concentrations of both $\mathrm{NE}^{1}$ and $5 \mathrm{mHT}^{1} \quad(0.5-5.0$ $\mathrm{ug} / \mathrm{ml}$ ) through the assay procedure. Recoverles from grain homogenates were $95 \pm 10 \%( \pm$ S.D., $N=6$ ) and $76 \pm 8 \%$ ( \pm S.D., $N=12$ ) respectively for NE and 5-HT. Values were reported as uug of free base/g of brain tissue. Duplicates for NE determinations were run with each assay. Duplication between homogenates for each amine was of the order of $97 \%$ (S.D. $= \pm 3.3 \%$ ). Maynert and Klingman, (1962) reported a S.D. of $\pm 2.7 \%$.

1 Both amines were obtalned from Nutritional Biochemical Corp., Cleveland, Oh10. NE was used as the free base, whereas 5-HT was used as the Creatinine sulfate. 
Control Data

Before the resilts obtalned from these experiments is presented, the validity and variability of the control data should be discussed (TABLES $I m X V$ ). Durlng the chronio restraint experiment, controls were separated from experimental animals by one alosed door. Altrough no anfmals were restraired in the presence of control arimals, they were released from restraint In their presenoe. Aside from the presence of other species in the animal room, atveral other persons conducting researin were also present at various times. All of these factors, thereture, appeared to exert an inlluence as observad from the presentation of control data. Therefore, all animals (normal anj reserpinized) were subjected to an inconsistent type of stiess. It tack control value is compared against the mean value, this varlable Is demonstratable. Furthermore, the control animals present during this experiment also exhiblted a slight G.A.S. or thelr wn. The recovery txperiments following 1 mgikg reserpine a] so demonstrate the daly variability of controI data (TABIES I \& II).

The results presented and discussed in tris investigation have all been interpreted in light of this great variability, and were compared in some manner with a control value at the appropriate day or time of day.

Although the data presented demonstrat: re reit varetion (cortrol and experimental) as demonstrated ry the him standara deviations, the data presented ane considered gourate and val ia, due to the consistency of the values.

It should further be added that the organ welght rejationm ships expressed in the following tables and figures, were not 
expressed as relative welghts (welght/100 g of animal), but as absolute weights. This preference was utilized because of the large variation in the growth rates of different groups of animals (TABIE III).

FInalIy, aII values reported were analyzed statistically utilizing the student "t" test (Burn, 1052). The level of signiflcance used throughout this resarah was at the 0.05 level. 
IV. RESULTS AND DISCUSSION

Single and Repeated Dose Recovery Experiments

with Reserpine 
TABLE I

THE RECOVARY OF PITUITARY-ADRENAL FUNCTION AND BRAIN NOREP INEPHR INE AND SERO TON IN IEVELS FOLLOWING A

SINGIS DOSE OF RESERPIINE IN MLE ALBTHO RATS

\begin{tabular}{|c|c|c|c|}
\hline $\begin{array}{l}\text { HOUR } \\
\text { OE } \\
\text { DAY }\end{array}$ & $\begin{array}{c}\text { SERUMb } \\
\text { CORTICOSTERONE } \\
\text { (KS) }\end{array}$ & $\begin{array}{l}\text { BRA IN } \\
\text { SERO NON TI } \\
(5-\text { HT) }\end{array}$ & $\begin{array}{l}\text { BRA II } \\
\text { NOREP RNEPER IIE } \\
\text { (NE) }\end{array}$ \\
\hline & $\mathrm{ug} / 100 \mathrm{ml}$ & $u_{B} / B$ & $\operatorname{uug} / g$ \\
\hline $\begin{array}{l}12: 00^{\circ} \\
\text { A.M. }\end{array}$ & $\begin{array}{l}39.0 \pm 15.0^{8} \\
10.6 \pm 3.0(8)\end{array}$ & $\begin{array}{l}432 \pm 26 \\
586 \pm 87\end{array}$ & $\begin{array}{l}286 \geq 179 \\
481 \geq 61\end{array}$ \\
\hline $4: 00$ & $\begin{array}{l}27.0 \pm 11.8(8)^{\circ} \\
16.0 \pm 4.0(6)^{\circ}\end{array}$ & $\begin{array}{l}458 \pm 23 \\
578 \pm 51\end{array}$ & $\begin{array}{l}123 \pm 42 \\
250+79\end{array}$ \\
\hline $\begin{array}{l}8: 00 \\
\text { P.H. }\end{array}$ & $\begin{array}{l}17.0 \pm 10.0(8) \\
21.7 \pm 8.0(6)\end{array}$ & $\begin{array}{l}357 \pm 28 \\
486 \pm 64\end{array}$ & $\begin{array}{l}112 \pm 12 \\
343 \pm 160\end{array}$ \\
\hline $\begin{array}{l}8: 00 \\
A . H\end{array}$ & $\begin{array}{r}10.3 \pm 3.0(8) \\
9.0 \pm 5.0(6)\end{array}$ & $\begin{array}{l}443=33 \\
529=90\end{array}$ & $\begin{array}{l}215 \pm 112 \\
623=34\end{array}$ \\
\hline
\end{tabular}

a - The dose of reserplne was $1 \mathrm{mg} / \mathrm{kg}, I, P$.

b - The values in this oolumn represent the mumber of animals atudied. For brain asajs pools of two bralns eaoh were used. - Slgnifloant rrom control values. AII values are means
B.D.

o. - All animals wore adminietered ofther drag or vehiclo at 8:00 A.M. The lower values at each hour (borizontal) are oontrol values. 


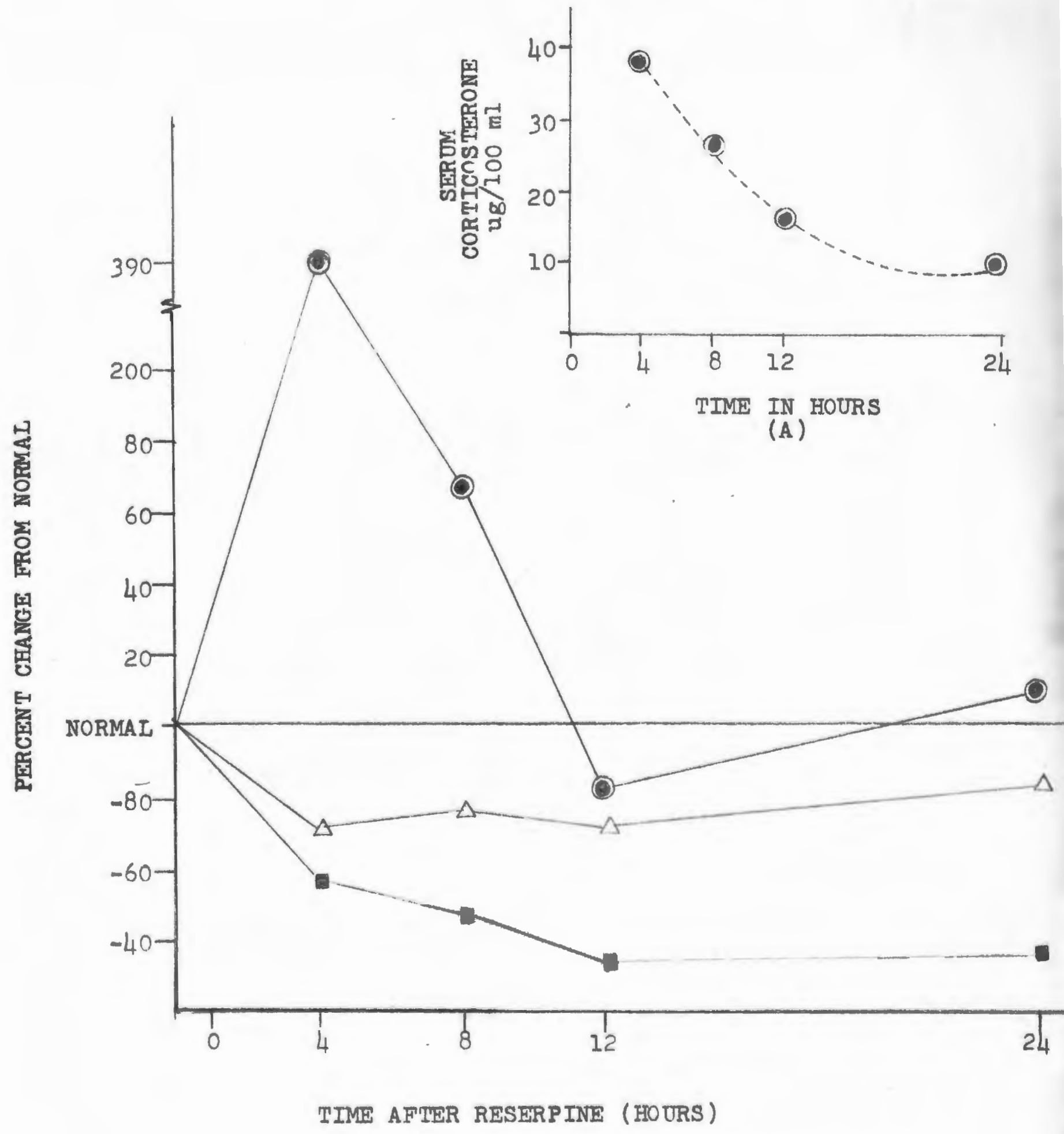

F1B. 2. The relationship botween pltu1tary-adrenocortical rosponses and brain neurohumoral ohanges following a aingle dose of reserp ine ( $1 \mathrm{mg} / \mathrm{kg}, \mathrm{I.P}$.

Levels of semum oortioosterone ( $\mathrm{d}$ ), brain serotonin $(\Delta-\Delta)$ and brain norepinephrine ( $-r$ ) were given. Each point represents the mean of either 6 to 8 animals or 3 to 4 brain pools ( 2 brains/pool)

(A) This ourve represents the actual serum cort1costerone changes following a alnglo dose of reserpine. 
TABLE II

THE: RECC VERY OF PITITITARY-A RRENAL, TINCTION ANT BRAIN NOREPINEPHRTNF AND SEROTONIN LEVELS FOLLOWING REPEATED DAIIYY DOSES OF RESERPINE (32 Days)a

\begin{tabular}{|c|c|c|c|}
\hline TTME ${ }^{b}$ & $\begin{array}{c}\text { SERUM }^{\mathrm{C}} \\
\text { CORTICOSTERONE } \\
(\mathrm{KS})\end{array}$ & $\begin{array}{c}\text { BRA IN } \\
\text { SERO TON IN } \\
(5-\mathrm{HT})\end{array}$ & $\begin{array}{c}\text { BRA IN } \\
\text { NOREP INEPHRINE } \\
\text { (NE) }\end{array}$ \\
\hline hr & $u u g / 100 \mathrm{ml}$ & $\operatorname{uug} / g$ & uxug/g \\
\hline 8 & $\begin{array}{l}27.9 \pm 10.5(10) \\
25.0 \pm 12.0(8)\end{array}$ & $\begin{array}{l}422 \pm 83 \\
605 \pm 77\end{array}$ & $\begin{array}{l}165^{\mathrm{d}} \\
498 \pm 191\end{array}$ \\
\hline 24 & $\begin{array}{r}9.5 \pm 4.0(6) \\
15.8 \pm 6.0(6)\end{array}$ & $\begin{array}{l}973 \div 546^{8} \\
534 \div 29\end{array}$ & $\begin{array}{l}163 \pm 23^{9} \\
623 \pm 29\end{array}$ \\
\hline 80 & $\begin{array}{l}16.0 \pm 8.0(8) \\
27.3 \pm 9.0(6)\end{array}$ & $\begin{array}{l}620 \pm 200 \\
563 \pm 69\end{array}$ & $\begin{array}{l}106 \pm 23^{\mathrm{s}} \\
645 \pm 168\end{array}$ \\
\hline 152 & $\begin{array}{l}47.0 \pm 18.5(4) \\
34.0 \pm 17.0(8)\end{array}$ & $\begin{array}{l}495 \pm 92 \\
697 \pm 123\end{array}$ & $\begin{array}{l}247^{\circ} \\
399 \pm 92\end{array}$ \\
\hline
\end{tabular}

a - The dose of reserpine was $1 \mathrm{mg} / \mathrm{kg}$, I.P.

b - Time refors to time after the last dose of reserpine.

c - The values in this column represent the number of animals studied. For brain assays pools of two brains each were used.

d - Two of 3 brains assayed exhibited no NE.

e - Represents a pooled value (l brains).

s - Slgnifloant from control values. All values are ineans \pm S.D. 


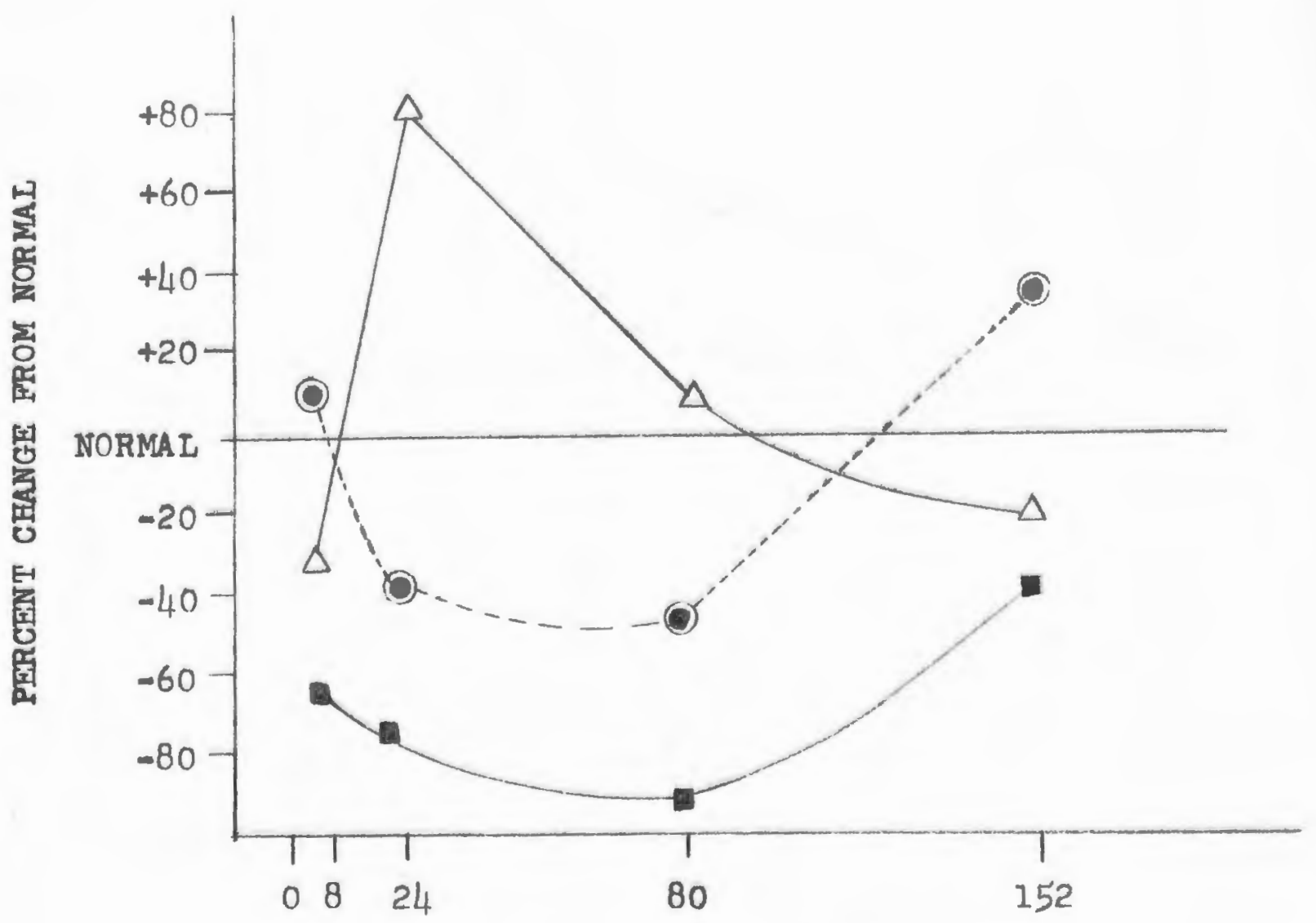

TIME AFTER RESERPINE (HOURS)

Fig. 3. P1taltary-adrenocortical and brain neurohumoral recovery following thirty-two doses of reserpine (1 $\mathrm{mg} / \mathrm{kg}$, I.P.) Levels of serum corticosterone (O-O), brain norepinephrine (- - ) and bra1n serotoni. ( $\Delta-\Delta)$ were given. Time refers to the number of hours followlng the last dose of reserpine. Each point represents the mean of 4 to 8 animals or 2 to 4 pools of brains (2 brains/pool) 


\section{DISCTSSICIT}

Reserpine (I mg/kg, I.P.) was observed to produce acute pituitary-adrenocortical activation as indicated by the Increase in semam ISS levels four hours following its administration (TABIE I, FIg. 2). This effect was not observed to be contimous with reserpine-induce sedation since at the time of maximal sedation, $8-12$ hrs following its administratIon, serum KS levels were elther decreasing or below normal levels. A similar lack of correlation was also observed with brain NE and 5-HT depletion. Therefore, pituitary-adrenocortical activation did not appear to be dependent upon brain NE or 5-HT levels nor upon reserpine-1nduced sedation. These results are in direct conflict with the work of Westermann et al (1962) who have shown a relationship between reserpinedepletion of brain 5-HT and Increased serum KS levels. Since these investigators did not preinject their animals prior to arug administration, they may not have observed the desired speciflc effect necessary for such a conclusion.

Reserplne also appeared to inblbit the diurnal varlation of serum KS levels at 4:00 P.M. (TABLE I). Whether this effect was induced by sedation or via pituitary exhaustion is not clear. The significance of this finding, however, is evident after reading the papers of Westermann et al (1962) and Montanar1 and Stockham (1962). These workers have neglected to analyze thelr own data in light of dally semu KS varlation, 
or have made no mention of its presence. Therefore, it is difficult to imagine how the se workers could conclude that reserpine-induced pituitary-adrenocortical activation was continuous with its sedative effects. As one can see, reserpine appears to possess a stimlating effect when considering actual KS levels (TABLE I, Fig. 2A)), whereas when compared to control levels, inhibition is evident (at 4:00 P.M.).

Recovery from chronic reserpine administration $(1 \mathrm{mg} / \mathrm{kg}$, I.P.), however, appears to produce an Inhibition of the pitu1tary-adrenocortical axis varlation 24 hrs following its admin1stration (TABLE II, Flg. 3). The decreased serum KS values 80 hours following the last dose of reserpine suggests pititu1tary-adrenocortical inhlbition by reserpine. This fact is further verifled by the apparent adrenocortical compensation demonstrated by increased semum levels 152 hours following the 32nd dose of reserpine. Since semm levels were slightly Ebove normal 8 hrs following reserpine administration on the 32nd day, subsequent pitultary-adrenocortical inhibition may have resulted from exhaustion of this system.

As observed throughout this experiment, the onset of reserpine sedation appeared about 4 hrs following 1 ts administration with maximal sedation appearing $8-12$ hrs later. Recovery from sedation was evident by $24 \mathrm{hrs}$. In contrast, throughout the latter half of the chronic recovery experiment several animals were abnormaliy excitable 24 hrs following a previous dose of reserpine. These animals were extremely excitable and very sensitive to handling. They also frequently fought amongst themselves. 
The development of acute sedation correlated well with decreased $\mathrm{NE}$ levels, whereas brain 5-HT depletion reached a maximu four rours following reserpine administration and was maintained at this level throughout the 12 th hr (TABIE I, Fig. 2). Twenty-four hours following a single dose of reserpine brain 5-HT appears to be returning to normal in contrast to brain NE. Since sedation was also minimal at tris time, brain 5-HT appears to be a better candidate as mediator of reserpine-induced sedation. Although these results are in conflict with the work of Brodie et al (1960) concerning equivalent depletion of both amines by reserpine, they do support his theory that reserpine mediates its effects through 5-HT depletion rather than $N E$ depletion.

The recovery of brain 5-HT levels following thirty-two doses of reserpine took on a different character. Brain 5-HT levels were $80 \%$ above normal 24 hrs after the last dose of reserpine (TABIE II, Fig. 3). This increased level corresponded well with the behavioral exc1tablilty observed.

Since the appearance of maximal sedation was equaliy present 8 hrs following the administration of reserpine throughout the chronic experiment, this time was used to compare all data. When comparing the effects of reserpine on brain neurohumoral levels after one and thirty-two doses of reserpine, equivalent progressive depletion of both amines was apparent (TABLES I and II). However, 1n subsequent experiments reserpine appeared to induce a greater progressive effect on brain NE than on 5-HT. The following table has been prepared to summarize this and subsequent experiments in order to clarify the preceding statements. 
TABLE IIA

A COMPARISON OF THF, EFFECTS OF RESERPTNE ON BRA IN NE AND 5-HT LEVELS OBTAINED FROM DIFFERENT EXPER IMENTS

\begin{tabular}{lccc}
\hline & $\%$ DEPLETION \\
\hline & DAY 1 & DAY 32 & $\begin{array}{c}\text { PROGRESSIVE } \\
\text { DEPIETION } \\
\text { DA I DAY 32 }\end{array}$ \\
\hline $5-\mathrm{HT}$ & $26 \%$ & $31 \%$ & $16 \%$ \\
$\mathrm{NE}$ & $37 \%$ & $73 \%$ & $51 \%$ \\
\hline
\end{tabular}

a - The values presentad are the means of experiments conducted in subsequent experiments; TABLES I, II, XI, XII, and $X V$. of DEPLETION refers to the percent of control values at that time.

Therefore, reserpine does appear to have a greater chronic effect on brain NE levels than on brain 5-HT levels when comparing the progressive depletion of both amines (TABLE IIA). It should be added that confirmation has since been obtalned in this laboratory which re-emphasizes the results of TABLE IIA. These observations coupled with the righ brain 5-HT levels observed with chronic recovery experiments (TABLE II), could be explained on the basis of an increased rate of 5-HT synthesis.

In relation to the hypotheses formulated inftially, the following observations can be made.

I - As Indicated by the serum KS levela after one and thirty wo doses, reserpine stimulates the pitultaryadrenocortical axis acutely, but apparently loses 


$$
\begin{aligned}
& \text { Its effect during chronic administration. However, } \\
& \text { whether the lack of a chronic effect was due to } \\
& \text { pitultary exhaustion it is not clear. } \\
& 2 \text { - The comparative effect of reserpine cn brain } \mathrm{NE} \\
& \text { Ievels was greater than on } 5 \text {-HT levels after single } \\
& \text { and thirty-two doses of reserpine. The differences } \\
& \text { in brain levels could be due to an increased rate of } \\
& 5 \text { HT synthesis during reserpine treatment. }
\end{aligned}
$$


IV. RESTILTS AND DISCUSSION

Effects of Reserpine In Animals Subjected to Da11y Forced Restraint Stress 
EFFECTS OF CHRONIC RESTRAINT STRESS ON THE FOOD AND WATER BALANCE AND MORTALITY RATT OF NORMAL AND RESERPINIZED NALE ALBINO RATS $\left(32\right.$ days) ${ }^{a}$

\begin{tabular}{|c|c|c|c|c|c|c|}
\hline & $\underline{n}$ & $\begin{array}{l}\text { WA TER } \\
\text { INTAKE }\end{array}$ & $\begin{array}{c}\text { URINE } \\
\text { EXCRETION }\end{array}$ & $\begin{array}{c}\text { MEAN } \\
\text { WEIGHT } \\
\text { CAIN/DAY }\end{array}$ & $\begin{array}{l}\text { FOOD } \\
\text { IN TAKE }\end{array}$ & $\underset{\mathscr{\%}}{\mathrm{M} \cdot \mathrm{R}^{\mathrm{b}}}$ \\
\hline & & $\mathrm{ml}$ & $\mathrm{m} 1$ & g & $g$ & $\not \%$ \\
\hline CONTROL & 8 & $38.7 \pm 4.1$ & $7.5 \pm 4.0$ & 3.88 & 18 & 0 \\
\hline STRESS & 8 & $41.6 \pm 4.3=$ & $7.8 \pm 2.1$ & 2.84 & 18 & 0 \\
\hline $\begin{array}{l}\text { CONTROL + } \\
\text { RESERPINE }\end{array}$ & 8 & $29.1 \pm 4_{4} .8^{x}$ & $3.5 \pm 1.7^{x}$ & 1.99 & 15.7 & 6.6 \\
\hline $\begin{array}{l}\text { STRESS + } \\
\text { RESERP INE }\end{array}$ & 12 & $24.8 \pm 6.7^{2}$ & $3.5 \pm 1.3^{x}$ & 0.50 & 12.6 & 50.0 \\
\hline
\end{tabular}

a - All values are means of 32 days/animal/day. Where indicated values are means \pm S.D. Dose of reserpine was $I \mathrm{mg} / \mathrm{kg}$, I.P.

b - Abbreviations - M.R. = Mortality Rate (\%Dead/Alive) $\mathrm{n}=$ Number of animals studied.

s - Signiflcant from control group.

$x$ - Significant from both the control and stress groups.

z - Signiflcant from all previous groups. All animals initially weighed about $160 \mathrm{~g}$. 
EFFECTS OF CHRONIC RESTRAINT ON THE THYMUS WEIGHTS OF NORMAL AND RESERPINIZED MAIE ALBTNO RATS ${ }^{a}$

\begin{tabular}{|c|c|c|c|c|}
\hline DAY & CONTROL & STRESS & $\begin{array}{l}\text { CONTROL + } \\
\text { RESERPINE }\end{array}$ & $\begin{array}{l}\text { STRESS + } \\
\text { RESERP INE }\end{array}$ \\
\hline & $m g$ & $m g$ & $\mathrm{mg}$ & $m g$ \\
\hline 1 & $\begin{array}{c}399 \pm 104 \\
(8)\end{array}$ & $\begin{array}{c}300 \pm 44_{4}^{5} \\
(8)^{5}\end{array}$ & $\begin{array}{c}320 \pm 62 \\
(8)\end{array}$ & $\begin{array}{c}369 \pm 61^{x} \\
(8)\end{array}$ \\
\hline 6 & $344=86$ & $24\} \frac{ \pm}{8} 2^{5}$ & $\begin{array}{c}313 \pm 149 \\
(8)\end{array}$ & $\left.23 \frac{1}{(8}\right)^{\mathrm{s}}$ \\
\hline 18 & $\begin{array}{c}432 \pm 97 \\
(8)\end{array}$ & $\left.324 \frac{ \pm}{8}\right)^{\mathrm{s}}$ & $\begin{array}{c}366 \pm 81 \\
(10)\end{array}$ & $\begin{array}{c}167^{ \pm 64^{9 x}} \\
(10)^{9 x}\end{array}$ \\
\hline 32 & $\frac{385 \pm 63}{(8)}$ & $324 \div 64$ & $298 \pm 69^{9}$ & $\frac{118 \pm 64^{s x}}{(12)^{s x}}$ \\
\hline
\end{tabular}

a - All values are means \pm S.D. Values in parentresis represent the number of animals used. Dose of reserpine was $1 \mathrm{mg} / \mathrm{kg}$, I.P.

s- Signiflcant from control group.

$x$ - Slgniflcant from streisi group. 
44

TABLE V

EFFECTS OF CHRONIC RESTRAINT STRESS ON THE TESTES WEIGHTS OF NORMAL AND RESERPINIZED MALE ALBINO RATS ${ }^{a}$

\begin{tabular}{|c|c|c|c|c|}
\hline $\mathrm{DAY}$ & CON'SROL & STRESS & $\begin{array}{l}\text { CONTROL + } \\
\text { RESERPINE }\end{array}$ & $\begin{array}{l}\text { STRESS + } \\
\text { RESERP INH }\end{array}$ \\
\hline & $m g$ & $m_{\mathcal{E}}$ & $m g$ & $\mathrm{mg}$ \\
\hline 1 & $1.88 \pm 0.28$ & $1.94 \pm 0.92$ & $1.79 \pm 0.30$ & $1.77 \pm 0.33$ \\
\hline 6 & $2.42 \pm 0.67$ & $2.14 \pm 0.52$ & $2.16 \pm 0.92$ & $2.11 \pm 0.40$ \\
\hline 18 & $2.96 \pm 0.50$ & $2.90 \pm 0.64$ & $2.74 \pm 0.45$ & $2.53 \pm 0.38$ \\
\hline 32 & $2.80 \pm 0.45$ & $3.11 \pm 0.54$ & $2.05 \pm 0.67$ & $2.20 \pm 0.87$ \\
\hline
\end{tabular}

a - All values are means $\pm S . D$. (None of the values presented here were significant from any other group). The number of animals studled appear in TABLE IV. Dose of reserpine was $1 \mathrm{mg} / \mathrm{kg}$, I.P. 
TABLE VI

EFEECTS OF CHRONIC KESTRAINT OH THU WET ADRENAL WEIGHTS OF NORMAL AND RESERPINIZED MALE ALBINO RATS

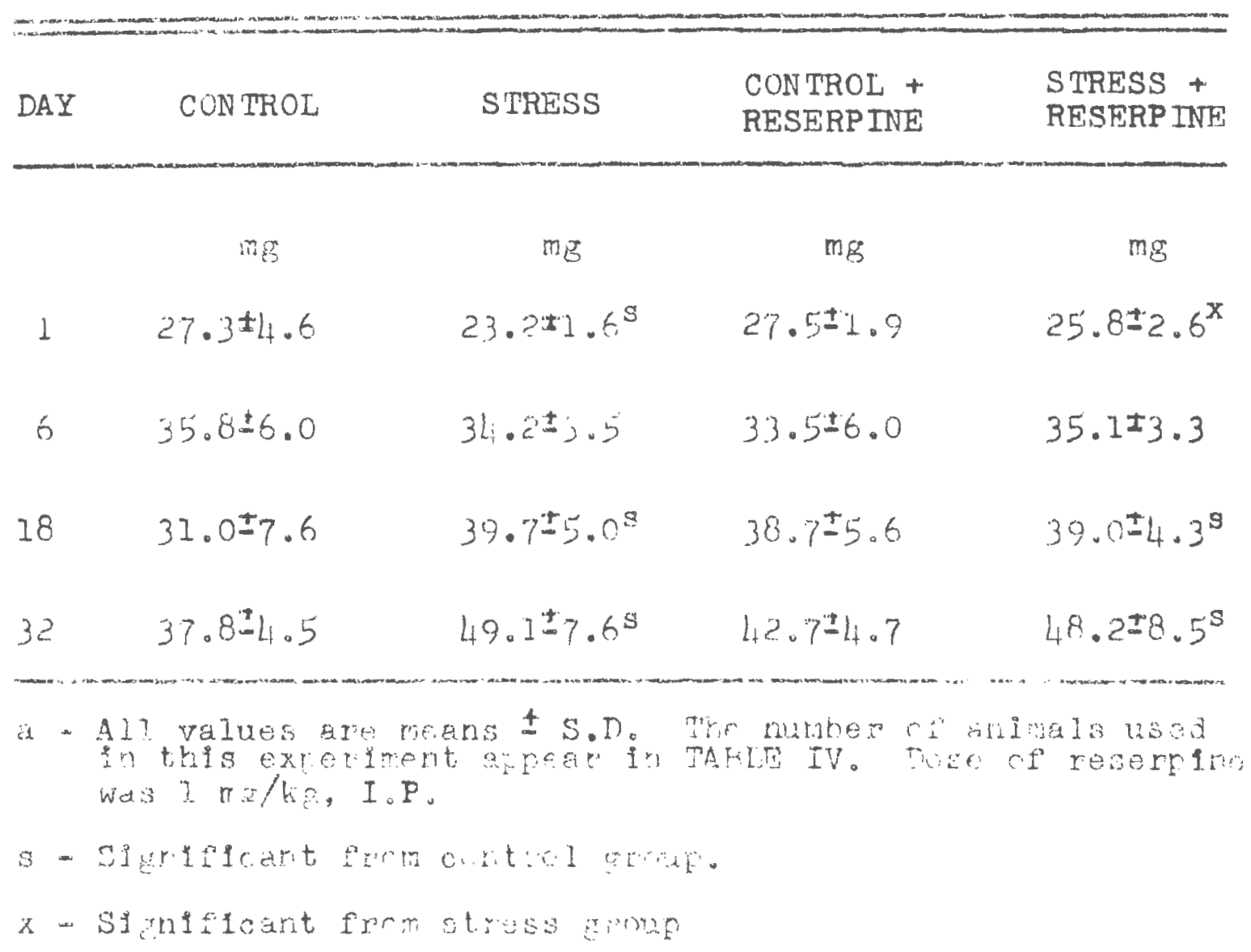




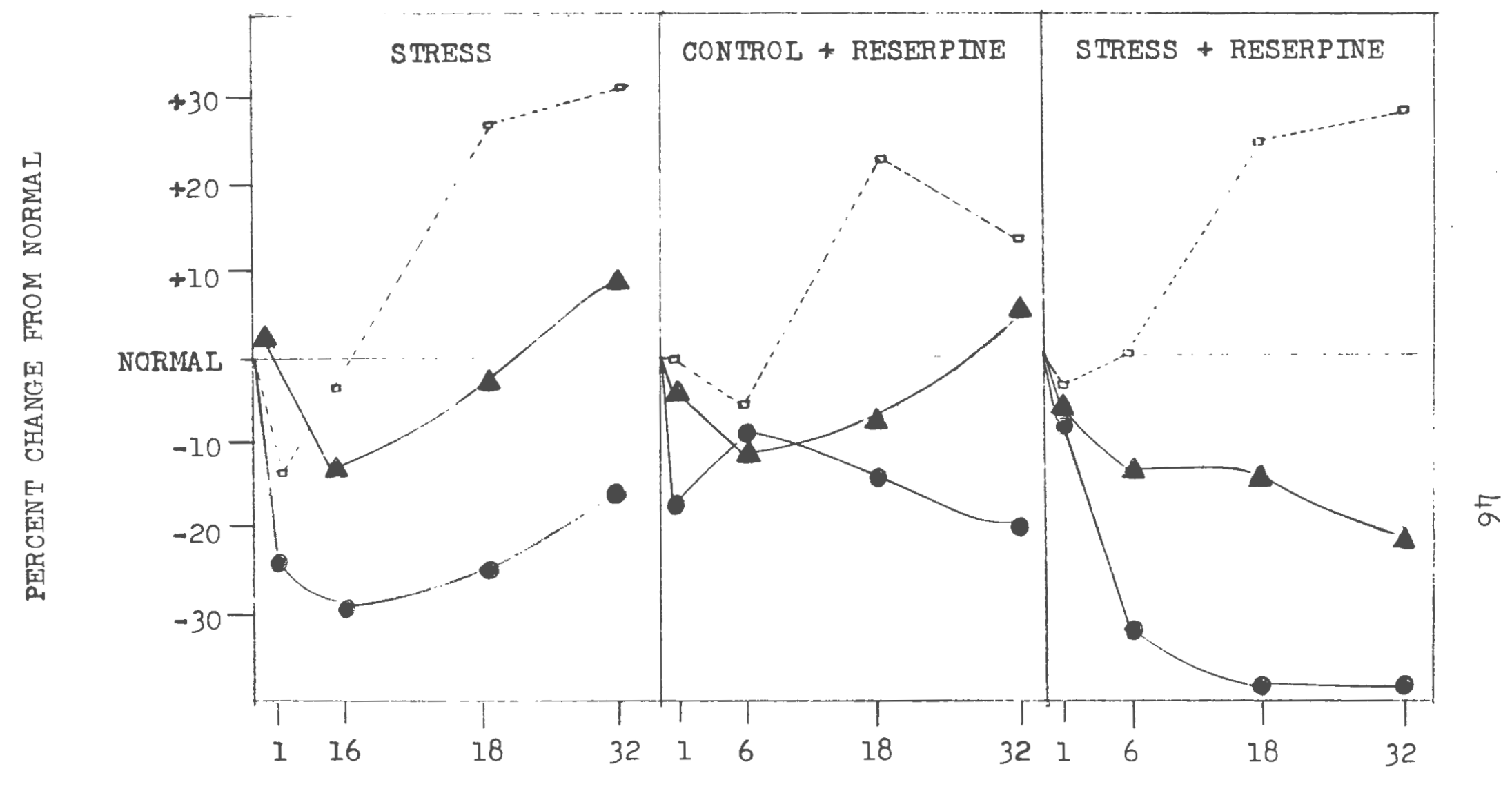

DAYS OF EXPERIMENT

Fig. L. A comparison of the effects of chronic restraint stress on various organ weights of normal and reserpinized male albino rats. The wei weights of adrenals $(a \cdots \infty)$, thyms ( - ) and testes ( $\Delta$ ) are given. Fach point represents the means of 6 to 12 animals. Dose of reserpine was $1 \mathrm{mg} / \mathrm{kg}$, I.P. 
TAEIE VII

EFFECTS OF CHRONIC RESTRAINT STRESS ON THE DRY ADRENAL WEIGHTS OF NORMAL AND RESERPINIZED MALE ALBTNO RATS ${ }^{\circledR}$

\begin{tabular}{|c|c|c|c|c|}
\hline DAY & CONTROL & STRESS & $\begin{array}{l}\text { CONTROL }+ \\
\text { RESERP INE }\end{array}$ & $\begin{array}{l}\text { STRESS + } \\
\text { RESERPINE }\end{array}$ \\
\hline & $m g$ & $\mathrm{mg}$ & $\mathrm{mg}$ & $m g$ \\
\hline 1 & $6.2 \pm 0.2$ & $5.6^{ \pm 0} 0.2^{9}$ & $6.8 \pm 0.8$ & $5.8 \pm 0.5^{5 x}$ \\
\hline 6 & $7.1^{ \pm} 7.6$ & $8.5^{ \pm} 0.4^{5}$ & $7.7^{ \pm} 1.6$ & $8.9^{ \pm} 1.3^{s}$ \\
\hline 18 & $8.2^{ \pm} 1.5$ & $10.5^{ \pm} 1.5^{5}$ & $9.8 \pm 1.8$ & $11.5^{4}=2.7^{5}$ \\
\hline 32 & $9.1^{ \pm} 0.4$ & $10.0 \pm 2.5$ & $12.3 \pm 2.9$ & $12.8 \pm 1.1^{8 x}$ \\
\hline
\end{tabular}

a - All values are means $\pm S . D$. The number of 7 nimals studied in this experiment appear in TABLE IV. Dose of reserpine was $1 \mathrm{mg} / \mathrm{kg}$, I.P.

s - Significant from control group.

$x$ - Significant from stress group. 
EFFECTS OF CHRONIC RESTRA INT ON THF $\%$

ADRENAL DRY WEIGHTS (ADW) OF NORMAL

AND RESERPINIZED MALE ALBINO RATS ${ }^{\mathrm{C}}$

\begin{tabular}{ccccc}
\hline DAY & CONTROL & STRESS & $\begin{array}{c}\text { CONTROL }+ \\
\text { RESERPINE }\end{array}$ & $\begin{array}{c}\text { STRESS }+ \\
\text { RESERP INE }\end{array}$ \\
\hline 1 & $23.0 \pm 4.1$ & $24.3 \pm 2.7$ & $24.8 \pm 1.5$ & $22.3 \pm 2.4$ \\
6 & $21.7^{ \pm 4.2}$ & $24.0 \pm 1.5$ & $25.3 \pm 1.3$ & $26.5 \pm 2.6$ \\
18 & $24.8 \pm 4.1$ & $26.4 \pm 1.6$ & $25.6 \pm .6$ & $29.2 \pm 2.5$ \\
32 & $24.7 \pm 2.7$ & $21.7 \pm 8.7$ & $27.4 \pm 4.2$ & $27.0 \pm 4.1$ \\
\hline
\end{tabular}

a - AII values are means \pm S.D. (None of the valuos presented here were sign'flicant from any other group). The number of animals studied appear in TABLE IV. Dose of reserpine was $1 \mathrm{mg} / \mathrm{kg}, \mathrm{I} . \mathrm{P}$. 
TABLE IX

EFFECTS OF CHRONIC RESTRAINI STRESS ON THE PITUITARY WEIGHTS OF NORMAL AND RESERPINIZED MHLE ALBINO RATS ${ }^{a}$

\begin{tabular}{|c|c|c|c|c|}
\hline DAY & CONTROL & STRESS & $\begin{array}{l}\text { CONTROL }+ \\
\text { RESERPINE }\end{array}$ & $\begin{array}{l}\text { STRESS + } \\
\text { RESERP INE }\end{array}$ \\
\hline & $w_{1}$ & me & $r_{1} g$ & mig \\
\hline 1 & 1.090 & $0.5 \%$ & 0.90 & 1.10 \\
\hline 6 & 1.67 & 1.05 & 1.30 & 1.28 \\
\hline 18 & 1.71 & 1.65 & 1.57 & 1.25 \\
\hline 32 & 1.76 & 1.89 & 1.56 & 1.54 \\
\hline
\end{tabular}

- The dry pltultaries from each group were poolod (6-8 pitultarles) tor accurate welghing anu are expressed as mg/animal (mean value). Dose of $\mathrm{l}^{\circ} \Theta \mathrm{serpino}$ was $1 \mathrm{mg} / \mathrm{kg}, \mathrm{I}$. P. 


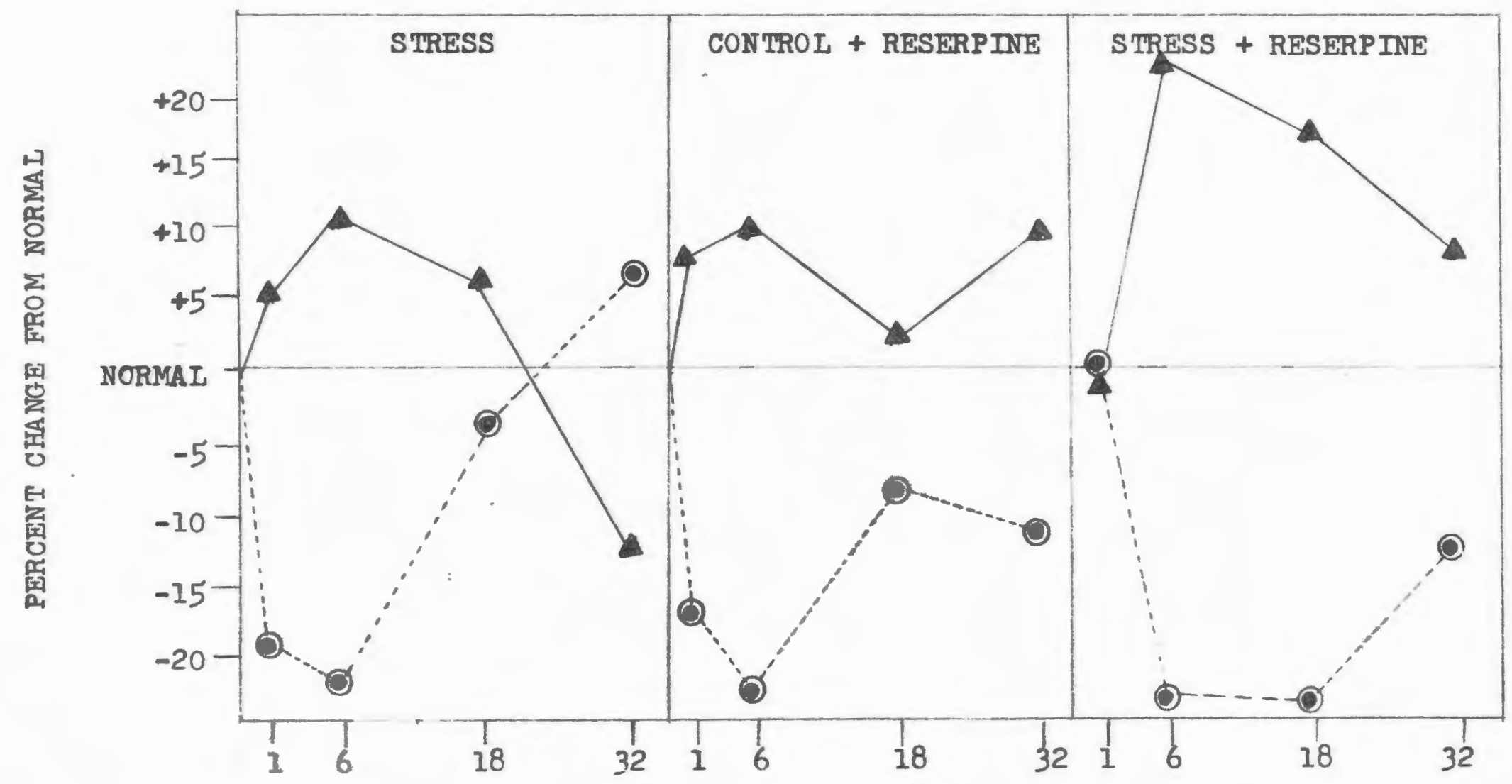

DAY OF EXPERIMENT

Plg. 5. A comparison of the effect of chronic restraint stress on pitultary-adrenocortical function of normal and reserpinized male albino rats.

The welghts of dry pituitaries (G-C) and $\%$ adrenal dry welghts (A-A) were given:- Each point represents the mean of 6 to 12 animals. Dose of reserpine was $1 \mathrm{mg} / \mathrm{kg}, \mathrm{I} . P$. 
EFFECTS OF CHRONIC RESTRAINT STRESS ON THE SERUM CORTICOS TERONE IEVELS (KS) OF NORMAL AND RESERPINIZED MALE ALBINO RATS ${ }^{2}$

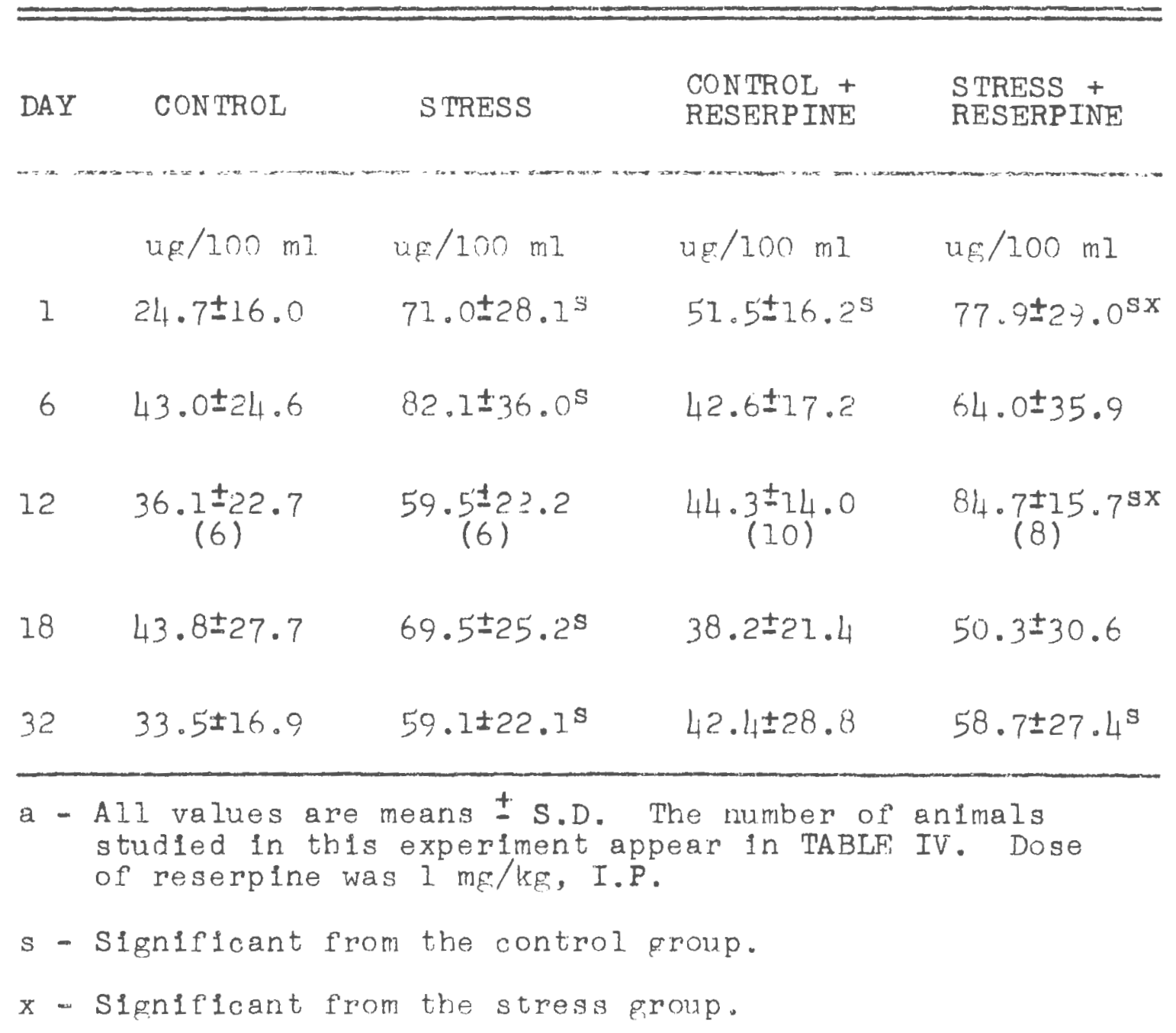


TABLE XI

EFFECTS OF CHRONIC RESTRAINT STRESS ON BRATN SEROTONIN (5-HT) LEVELS OF NORMAL AND RESERPINIZED MAIE ALBINO RATS ${ }^{2}$

\begin{tabular}{|c|c|c|c|c|}
\hline DAY & CONTROL & S'TRESS & $\begin{array}{l}\text { CONTROL + } \\
\text { RESERPINE }\end{array}$ & $\begin{array}{l}\text { STRESS + } \\
\text { RESERPINE }\end{array}$ \\
\hline & $\mathrm{ug} / 100 \mathrm{ml}$ & $\mathrm{ug} / 100 \mathrm{mI}$ & $12 \mathrm{~g} / 100 \mathrm{mI}$ & $\mathrm{ug}_{\mathrm{g}} / 100 \mathrm{mI}$ \\
\hline 1 & $\begin{array}{c}796+43 \\
(4)\end{array}$ & $\frac{961 \pm 210}{(4)}$ & $485 \div 125$ & $\frac{850 \pm 137}{(4)^{2}}$ \\
\hline 6 & $\begin{array}{c}698 \pm 43 \\
(3)\end{array}$ & $\begin{array}{c}1426 \pm 823 \\
(4)\end{array}$ & $\begin{array}{c}567 \pm 111 \\
(4)\end{array}$ & $\begin{array}{c}960 \pm 443 \\
(4)\end{array}$ \\
\hline 12 & $\left.67 \frac{4}{4}\right)^{-14}$ & $673+63$ & $522 \div 187$ & $\left.627 \div \frac{64}{3}\right\}$ \\
\hline 18 & $737 \pm 148$ & $\frac{525 \pm 260}{(5)^{60}}$ & $\frac{482 \pm 45}{(4)}$ & $605 \div 41$ \\
\hline 32 & $697 \pm 123$ & $\left.554 \frac{1}{5}\right)^{23}$ & $\frac{482 \pm 167}{(6)}$ & $\begin{array}{c}605+149 \\
(6)\end{array}$ \\
\hline
\end{tabular}

a - All values are means IS.D. The number of brain pools studied is represented in the parenthesis (2 brains) pool). Dose of reserplne was I $\mathrm{mg} / \mathrm{kg}, \mathrm{I} . \mathrm{P}$.

s- Slgnificant from control group.

$y$ - Slgniflcant from control + reserpine group. 
TABIE XII

\section{EFEECTS OF CHRONIC RESTRAINT STRESS ON THE BRAIN NOREPINEPHR INE (NE) IEVELS OF NORMAL AND RESERPINIZED MALE ALBINO RATS ${ }^{\circ}$}

\begin{tabular}{|c|c|c|c|c|}
\hline DAY & CON TROL & STRESS & $\begin{array}{l}\text { CONTROL + } \\
\text { RESERPINE }\end{array}$ & $\begin{array}{l}\text { STRESS + } \\
\text { RESERP INE }\end{array}$ \\
\hline & $u u g / g$ & $u u g / g$ & uug/g & $u u g / g$ \\
\hline 1 & $242 \pm 68$ & $196 \pm 61$ & $182 \pm 123$ & $177 \pm 82$ \\
\hline 6 & $340 \pm 218$ & $137 \pm 86$ & $182 \pm 91$ & $199 \pm 52$ \\
\hline 12 & $-\infty-\infty--$ & $--\infty-\infty-$ & $161 \pm 16$ & $231 \pm 37$ \\
\hline 18 & $590 \pm 188$ & $497 \pm 190$ & $118 \pm 12^{8}$ & $122 \pm 64^{3}$ \\
\hline 24 & $507 \pm 74$ & $560 \pm 38$ & $48-88$ & $102-305$ \\
\hline 32 & $399 \pm 96$ & $318 \pm 23$ & $128 \pm 61^{3}$ & $112 \pm 73$ \\
\hline
\end{tabular}

a - All values are means $\pm S . D$. The number of brain pools studied appear in TABIE XI. Dose of reserplne was I $\mathrm{mg} / \mathrm{kg}$. I.P.

s- Signiflcant from control group. 


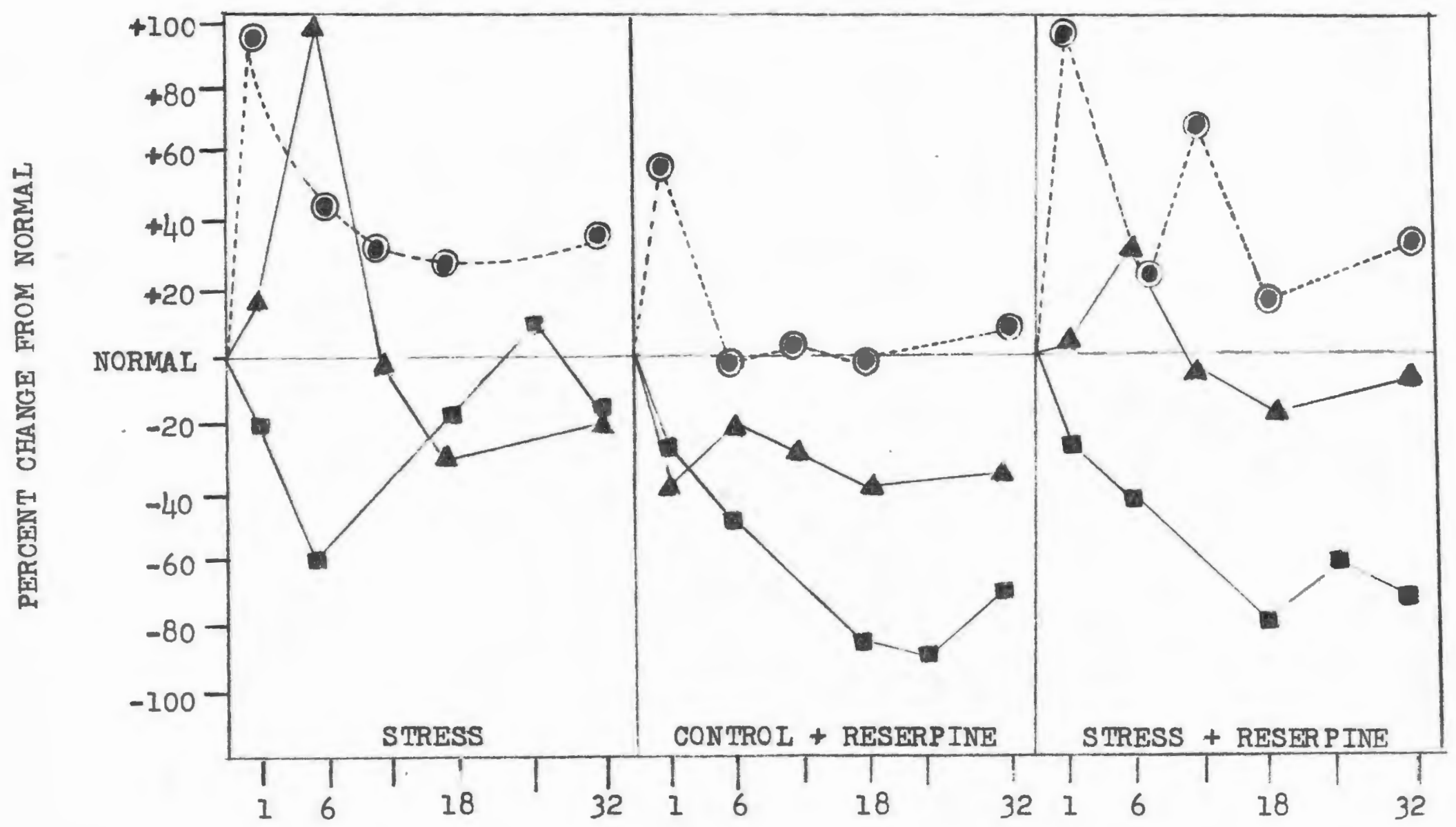

DAY OF EXPERIMENT

F1g. 6. A comparison of the effects of chronlo restralnt stress on semum cort1costerons levels and brain neurohumoral levels.

Levels of corticosterone (O-C), brain norepinephrine $(-\mathrm{C})$ and

brain serotonin ( $\longrightarrow$ ) were given. Actual serum $k s$ changes are obtalned bv doubiling the values appearing above. Fach point repfesents the means of either 6 to 12 animals or 3 to 6 brain poois (2 brains/pool). Dose of reserpine was $1 \mathrm{mg} / \mathrm{kg}$, I.P. 
DISCTISSION

The Effects of Chronic Restraint (RS) on the Pituitary-Adrenal Axis and Varlous Organ Weights of Normal Male Albino Rats According to Selye's theories regarding ehronic stress, animals respond differently to individual stressors only in a quantitative way; the responses all belng qualitatively the same. Therefore, one of the first objectives of this experiment was to characterize the effects of chronic restraint stress in normal animals in terms of the G.A.S.

It was found difficult to completely characterize the alarm reaction, sirce experiments were desizned at six day intervals (the alarm reaction usually occurs within the flrst three de ys of chrinic streis). The alirm reaction was ericunt to some degree by the significant decrease of the thymus welght of stressed animals on day one (TABIF IV). T'bere wai also a noted decrease in the pitultary weight which was also observed by Turner and Tinerty (1956) (TABLE IX). It is difficult to analyze glandular activity from only a weight change, but on the basis of the severity of restraint stress, the loss of weight could be due to ACTH and assoclated chemlcal depletion during extreme activation.

The significant decrease in wet and dry adrenal weights of normally stressed rats after the first day of the experiment (TABLES VJ VII) wás extremeIy interesting and unexpected. In contrast to this effect, selye (1050) bas observed an increase 
of adrenal welght during. the alarm reaction indicating adrenal hyperfunction. This effect could also be interpreted as Indicating adrenal exhaustion caused by this stress. This fact, however, seems highly urlikely.

Another unexpected finding was the inftial lack of effect of RS on the testes welght, which according to selye (1950), should decrease following an acute stress. The present finding was confirmed by Albert (1942) who observed a delay in decrease of gonadal welghts following chronic formalin stress $10.2 \mathrm{ml}$, I.M.). This was also observed in this experiment (TABIEV). The ablilty of normal male albino rats to adapt to chronlc restraint stress is evident after studying the effects of this stress on the thymas, testes, adrenal and pituitary welghts (Figs. 4 \& 5). Following the inftial alarm reaction the convergence of all changes towards original or normal levels is an excellent example of animal adaptation to external environmental changes.

The inverse relationsip which exists between the pituitary dry weight and FADW of stressed rats appears to be one of the clues which may aid in explaining pitultary-adrenal adaptation (TABLES VIII-IX: Fig. 5). This relationship appears to confirm the earlier observation that a decrease in pituitary weight could be interpreted as indicating a state of hyperfunction. Thus, as an anfmal adapt: to a stressor, the pituitary becomes less active as indicated by the progressive increase of dry pituitary (Fig. 3). The progressive decrease in the \%ADW also Indicates a similar decrease in adrenal function. 
Although an apparent decrease in pltultary and adrenal function prevails during adaptation to stress, the serum corticosterone (KS) levels exhibit no relative adaptation and appear to be maintained at high levels throughout the experiment (TABLE X, F1g. 6). If the adrenal weights are an indication of corticosteroid synthesis ard release, then the concurrent maintenance of both serum KS and ADW would indicate an Increased adrenaI efflclency during adaptation to stress (TABLES VIII and $X$ ). Tht Iffects of Chronic Restraint (RS) on the Pltuitary-Adrenal Axis and Various Organ We1ghts of Reserpinized Male Albino Rats The mortality rate of roserpinized rats subjected to RS was oxtremely high (50\%, TABLE III), and clearly indicates the Inablilty of reserpinized animals to adapt to chronle forced restraint stress. The reserpinized animals subjected to stress appear to die from starvation effects whlch seemed to stem from their inability to adapt to the stress since normal reserpinized animals demonstrated a mortality rate one-fifth that of the stressed animals. The decreased water and food balance caused by reserpine, attests to this nondaptation.

The most striking effect of reserpine on the first day Was its apparent inhibition of the effects of RS on the organ welghts (thymus, pitultary and adrunal) of normal aulmals (TABLES IV, VI-IX, FIgs. 4 and 5). It inbibitad the weloht changes by approximately 50\%. Tho effucts of rearpine on the testes of stressed animalis is also interestine aince it appeared to act independently of tho stress by producing a decrease in welght (TAPIS V). 
Although reserpine apparentiy inbibits stress on the first day, thereafter, nonadaptation prevails. As observed in Figs. 4 and 5 , organ welght changes are divergent in contrast to untreated animals under stress. There were some signs of adaptation as indicated by the increased pltultary welght and decreased \%ADW on the thirty-second day (Fig. 5).

The serum corticosterone levels indicate that reserpine does not prevent anlmals from achieving adrenal adaptation since the se levels are equivalent to those of untreated stressed an 1mals (TABLE X, Fig. 6).

That this may not be the case is indicated by the apparent nonadaptation of the pltultary-adrenocortical axis (TABLES VI-IX). In all cases, the progressive increase of adrenal wet welghts and ADW's, would indicate increased adrenal function. The apparent decrease in dry pitultary welght (TABLE IX), would also tend to confirm continued stimulation. Since no other experimental evidence has been presented, these divergent results cannot be explained at present. However, the great alfference between the growth rates of stressed and reserpinized stressed animals, may offer some future explanation. The fact that starvation may inhibit the usual detoxication of corticosterone in the liver of rats (Herbst et al, 1960), may also aid in explaining this discrepancy.

Reserpine appeared to produce a significant effect of its own on the pitultary-adrenal axis. At times, especially at the onset of the experiment, the effects of reserpine on organ welghts of normal animals were almost mirror images of the effects of RS In tormal auimals (TABLES IV, V, IX, \& X). Another inter- 
esting effect appears on the pituitary gland itself (Fig. 5). The initial decrease of pituitary welght which occurred on day one could be caused by nonspecific effocts, and thus, may refiect a release of secretory substances. However, on the elghteenth day this effect could also be interpreted as complete pitultary exhaustion, as predicted by kitay et al (1959) and Malckel et al (1961). It is interesting to note that reserpine produces an equivalent effect on the pituitary on day one as does RS in normal animals. On the other hand, reserpine plus stress produces an inhlbition of the decreased pitultary welght as caused by stress alone. It thus appears that these effects on the pitultary may indicate different mechanisms which are antagonistic. Similar differences were also observed on the thymus and adrenal weights.

In a final analysis, reserpine appears to prevent adaptation to RS as evidenced by its divergent effects on varlous organ welght changes.

The Effects of Chronic Restraint (RS) Stress on the Behavior and Brain Serotonin (5w HT) and Norepinephrine (NE) Levels of Normal and Reserpinized Animals

Normal animals subjected to RS demonstrated an extreme degree of excltablity during the first six days of the experiment. This behavioral effect decreased progressively with the duration of the experiment indicating behavioral adaptation.

On the other hand, restrained reserpinized anime ls were less excitable at the orset of the experiment but became progressively more excltable and diffcult to handle as the experiment proceeded. During the latter half of the experiment reserpinized 
anirals appeared vicious as indicated by their attacks upon the investigator. To be more specific, reserpinized animals were quite easily tied down throughout the experiment, but became increasingly viclous upon release from restraint.

Generally, most of the stressed reserpinized animals displayed some degree of ptosis while under restralnt throughout most of the experiment. After the sixth day of the experiment, the feeble state of the animals (animals weighed about $140 \mathrm{~g}$ ) prevented an accurate analysis of the degree of ptosis and sedation. On about the twelfth day the reserpinized animals also ceveloped watery secretions around the eyes which made it even more diflicult to determine the degree of ptosis. Very infrequently normally stressed animals developed similar secretions.

To summarlze, reserpinized animals became progressively excltable upon release from restraint, although the stress was Initiated with greater ease than with the control animals. Thus, there were no indications that reserpinlzed animals evidenced any sort of behavioral adaptation to chronic RS.

There also appeared to be neurohumoral adaptation occurring concurrently with behavioral adaptation. The problem in analyzing these results is the fact that the $5-H T$ and NE brain levels of normally stressed animals were not signiflcantly different from control data (TABIES XI-XII). As seen in Fig. 6, there is an increase in brain 5-HT levels and a decrease in brain $N E$ levels whlch correspond very well with the ganeral activity of the stressed aninials during the flrst six days of tho experiment. As was pointed out above, these animals were extremely excited during the first six days of the experiment. 


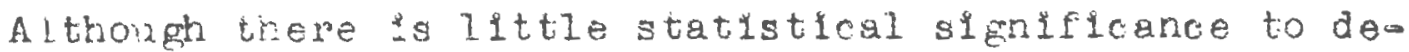
SEit the findizgs presented, the importarce of a possible coro relation between behavloral adaptation, and baan $5-H T$ and NE Leves must not be denled.

One of the most important observations made in this experiment was the fact that chronlc atress (RS) will inhlult the Uarai 5 HT releashng efrects produced by chronle reserpine adw mirstiation (TABLE XI, pig. 7). The effects of RS on brain NE rete larking as was previously demonstrated acutely by Broüle et al (1960). The slenifloance of these findinga will be dis cussea later. To determine whether chronla stress inhlbited rew serpine sedation as well as brain 5oHi was vexy dificult. In relation to the cortsiation betwer behaviorel sad netrohumoral adaptation in reserpinized aninais subjected to chronle stress, the figet that stress had no offect on brain NE levols appears to associate this amine with the progressive increased behavioral activl ty associated with this group of animals.

One point, however, was very obvious. Rsserpine did not Induce a progressive depletion of brain 5wT bit it ald to brain NE (F1g. 4). On the other hand, Brodie and Shore (1957) have

postulated that reserpine should produce a progressive depletion of both brain amines since they do so acutely. The above obser. vations were also present in the fulst experiment (TABLES I and II)。

\section{Summary}

In view of the bypotheses prosented earlier, this experio ment has certainly produced afteots whloh were not expectid. 
Therefore, the inftial hypothesis will now be discussed in relation to this experiment.

Hypothesis I - Reserpine has not been found to inhibit chronic restraint stress to any degree. In fact reserpine appears to be an acute stimilator of the pituitary-adrenocortical axis and appears to prevent animals from adapting to this stress. How reserpine prevents adaptation cannot be determined at present.

Hypothesis II - Reserpine does appear to ceplete brain 5-HT equaly throughout this experiment. The fact that brain NE was depleted progressively throughout this experiment in contrast to brain 5.HT, makes it impossible to conclude as to which neurohormone is responsible tor reserpine-induced-sedation. The fact that it was not possible to positively state whether chronic stress inhlbits reserpine sedation as it inhibited 5-HT release, gives added support to the preceeding statement.

Hypothesis III - Since there are no clear cut results which would either prove or disprove the stated hypotheses, there does appear to be secondary mechanisms which may be responsible for the observed effects.

The data obtalned by chronically stressing reserpinized rats has made 1t necosary to formate two anc1liary hypotheses. Hypothesis IA - If reserpine 1s specifloally stimulating the pltultary-arenal axis, thon wlugle and obunio pradod doses of reserpine abould produce gradod effects on this system.

Hypothesio IIA - Sinne reserpine did rot luduce a progreasive depletion of 5. H'l, but only of NE, and malntained an equivalent 
degree of sedation throuphout the experiment, it is postulated that reserpine is inducing a rapid 3 ynthesis af $5-H T$.

To test these hypotheses, a chronio graded dose experiment Luvolving rescroine was also conducted. The above byrutheses w11 be alscussed in view of these three major experiments. 


\section{RESUTIS AND DISCUSSTON \\ Effeots of Slngle and Repeated Graded Doses Reserpine 1n Normal Male \\ Albino Rats}


EFFECTS OF SINGLE GRADED DOSES OF RESERPINE ON PITUITARY-ADRENAL FUNCTION IN NORMAL AIBINO RATS

\begin{tabular}{|c|c|c|c|}
\hline DOSE & $\begin{array}{l}\text { ADRFNA L }{ }^{\mathrm{z}} \\
\text { DRY } \\
\text { WEIFHT } \\
\text { (ADW) }\end{array}$ & $\begin{array}{c}\text { SERTM } \\
\text { CORTICOSTERONE } \\
\text { (KS) }\end{array}$ & $\begin{array}{l}\text { WET } \\
\text { PITUITARY } \\
\text { WEIGHT }\end{array}$ \\
\hline $\mathrm{mg} / \mathrm{kg}$ & $\mathrm{mg} / 100 \mathrm{~g}$ & $\mathrm{ug} / 100 \mathrm{ml}$ & $m g$ \\
\hline$\left(\begin{array}{l}0 \\
4\end{array}\right) *$ & $4.3 \pm 0.1 \% 3$ & $16.0 \pm 4.0$ & $\ldots-\ldots$ \\
\hline$(6)$ & $4.6 \pm 0.7$ & $21.6 \pm 14.0$ & $4.6 \pm 0.7$ \\
\hline $\begin{array}{l}0.5 \\
(8)\end{array}$ & $3.4 \pm 0.5$ & $13.8 \pm 11.6$ & $4.2 \pm 0.9$ \\
\hline $\begin{array}{l}1.0 \\
(8)\end{array}$ & $4.4 \pm 0.2$ & $27.0 \pm 12.0^{8}$ & $3.8 \pm 0.6$ \\
\hline $\begin{array}{l}2.5 \\
(7)^{5}\end{array}$ & $4.6 \pm 0.5$ & $34.0 \pm 7.9 a$ & $4.4 \pm 0.8$ \\
\hline $\begin{array}{l}5.0 \\
(\dot{8})\end{array}$ & $4.0 \pm 0.3$ & $38.3 \pm 12.0^{2}$ & $5.3 \pm 0.5$ \\
\hline
\end{tabular}

* - Numbers in parenthesis represent the number of animals studied.

*Al - values are means \pm S.D.

a - Significant from the control group (0).

J - These animals were administered $2 \mathrm{ml} / \mathrm{kg}$ of a $25 \%$ solution of the reserpine vehicle.

$z$ - The organ weigtts presented are mg/loo $g$ of animal weight. 


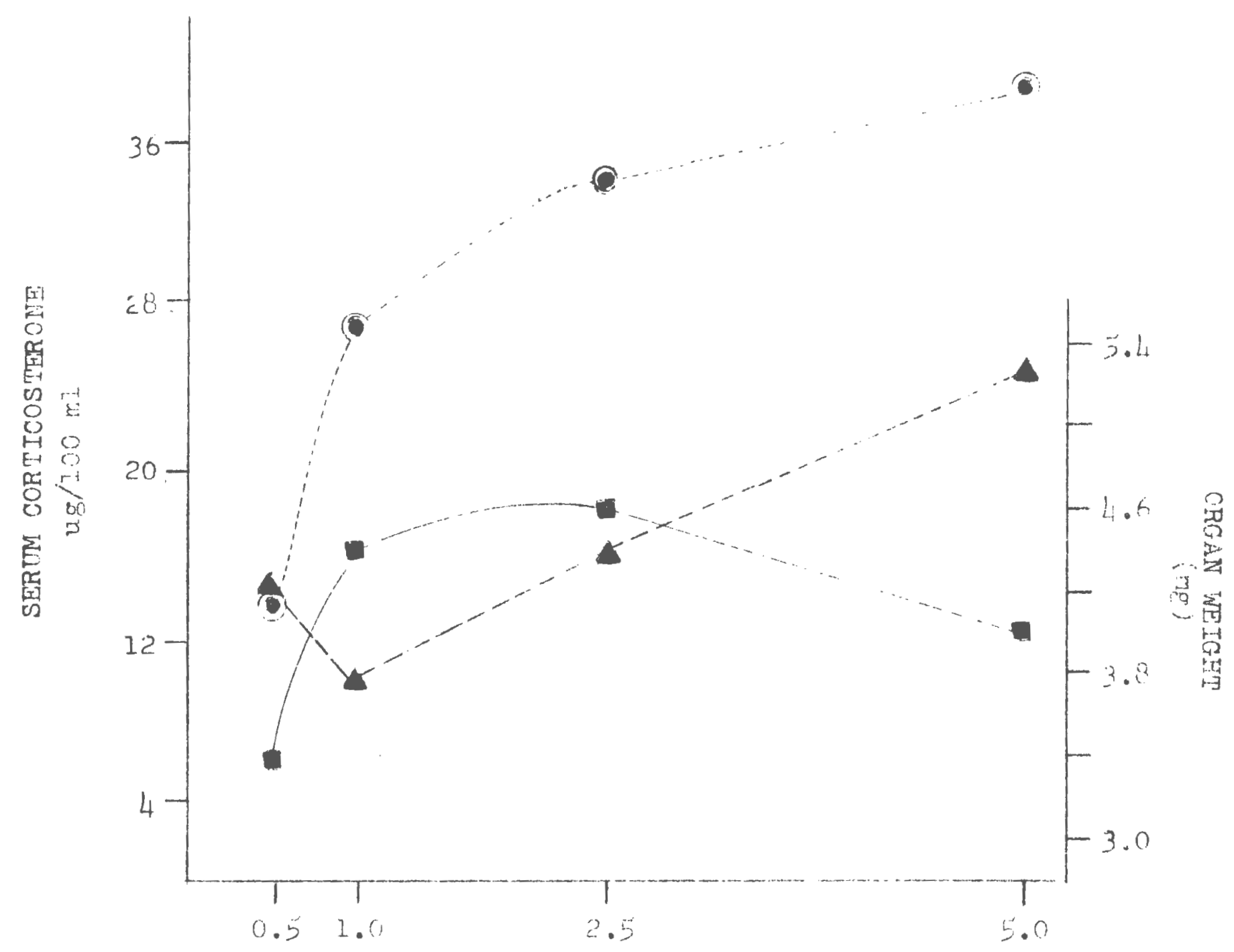

DOSF, OF RESERPINE

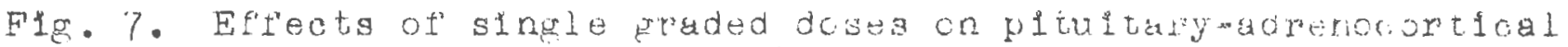
function in normal male al bilio rate.

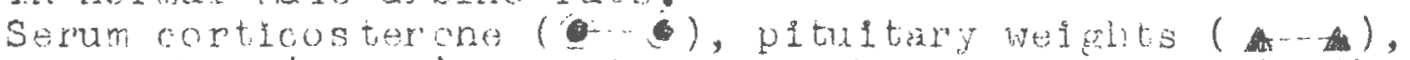

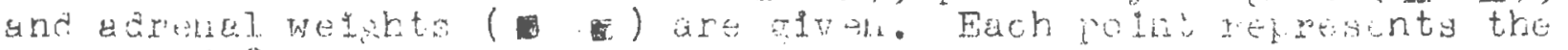
megn of 5 w $\operatorname{an} 1 \mathrm{mal} \mathrm{s}$. 
TABLE XIV

EFFECTS OF REPEA TIAD GRADED DOSES OF RESERPINE ( 32 days)

ON PITUITARY-ADRENAL FTINCTION IN NORMAL MALE

ALBINO RATS

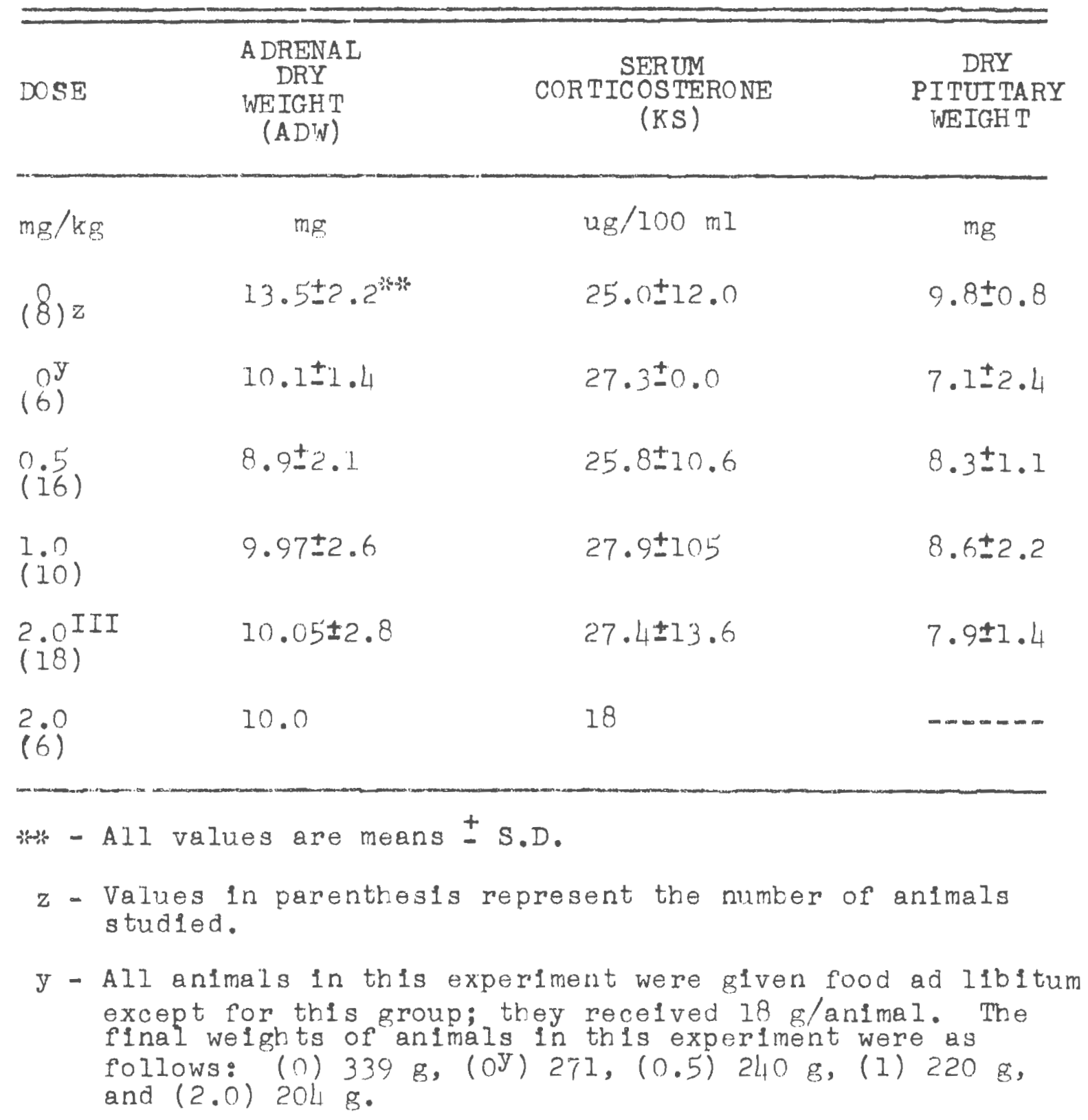


TABLE XV

EFFECTS OF SINGLE AND REPEATED GRADED DOSES OF RESERPINE ON BRA IN SEROTONIN AND NOREP INEPHRINE LEVELS OF NORMAL MALE ALBINO RATS

\begin{tabular}{|c|c|c|c|c|c|}
\hline \multicolumn{3}{|c|}{ SINGLE DOSES } & \multicolumn{3}{|c|}{$\begin{array}{l}\text { REPEATED IOSES } \\
(32 \text { Days })\end{array}$} \\
\hline DOSE & $5-\mathrm{HT}$ & $N E$ & DOSE & $5-\mathrm{HT}$ & $\mathrm{NE}$ \\
\hline $\mathrm{mg} / \mathrm{kg}$ & $\mathrm{uug} / \mathrm{g}$ & $u_{g} / g$ & $\mathrm{mg} / \mathrm{kg}$ & uug/g & ung/g \\
\hline$(4)^{*}$ & $577 \pm 51^{* * * *}$ & $245-77$ & 6 & $605 \pm 77$ & $498 \pm 191$ \\
\hline$(4)^{0}$ & $516 \pm 99$ & $129 \pm 84$ & $\begin{array}{l}0.5 \\
(5)\end{array}$ & $426 \pm 27$ & $\begin{array}{c}76 \pm 58^{\circ} \\
(2)\end{array}$ \\
\hline$(4)^{1}$ & $458 \pm 28$ & $123 \pm 39$ & (io) & $\begin{array}{l}427 \pm 87 \\
563 \pm 69\end{array}$ & $\begin{array}{c}72 \pm 51 \\
645 \pm 168 \\
(3)\end{array}$ \\
\hline 2.5 & $410 \pm 36$ & $191 \pm 36$ & $\begin{array}{l}2.0 \\
(4)\end{array}$ & $461 \pm 65$ & $\begin{array}{c}94 \pm 57 \\
(2)\end{array}$ \\
\hline $\begin{array}{l}5.0 \\
(\dot{4})\end{array}$ & $365 \pm 56$ & $148 \pm 39$ & $2.0^{I I I}$ & $\begin{array}{l}673 \pm 79 \\
789 * * 36\end{array}$ & $107 \pm 51$ \\
\hline
\end{tabular}

* Values in parenthesis represent the number of pooled assays $(2-4$ brains/pool).

w - All values are means \pm S.D.

सH* - These values are slgniflcantly different from the values above at $2 \mathrm{mg} / \mathrm{kg}$. The values below repregent a pool of three assays.

III - Extremely excitable group.

a - The values in parenthesis in th is column represent the number of assays in which NE could not be determined. 


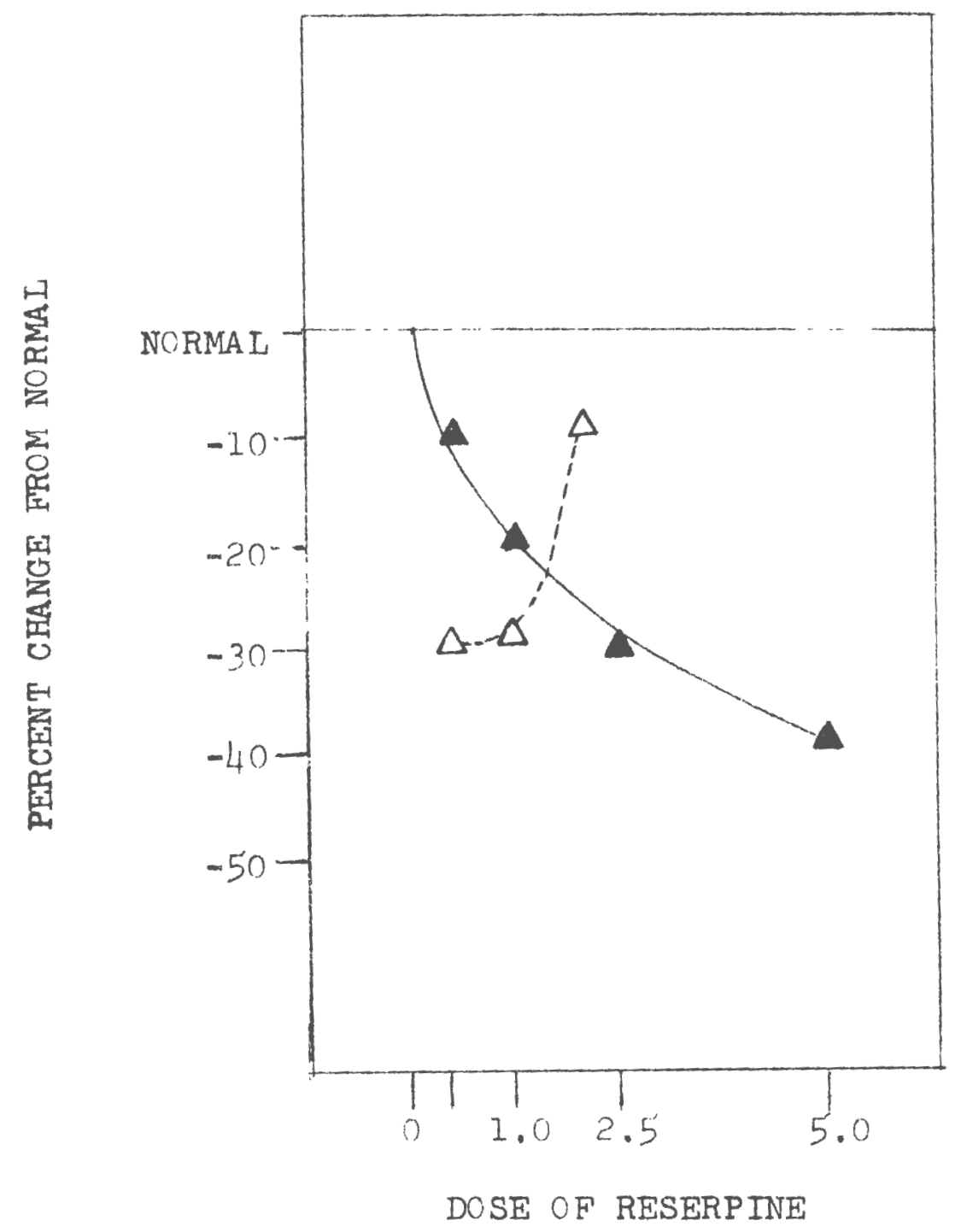

Flg. 8.' Effects of single and chronic graded doses of reserpine on brain serotonin (5-HT) levels of normal male albino rats.

Single doses $(\Delta-\Delta)$ and chronle doses $(\Delta \cdots \Delta)$ are given. Each point represents the mean of 3-7 brain pools (2-4 brains/pool). The chronic experiment was conducted for 32 days. 
DISCUSS ION

single of taded aoses of reserpine resulted in a dose-response effect on the p1tu1tary-adrenal axis (TABIE XIII, F1g. 7). The olgmold character of semm KS levels doos Indicate a specific stimulatory effect by reserpine. The attempt to permit animal adaptation to the vehicle and injection by two weeks of preingection re-empharizes the spec1flo effects of reserpine on tris system. However, the vehlclo was also adminlstered in a greater dose (0 $0^{\circ}$, TABIE XIII). As indicated, this conoentration also had an effect on the pitultary-adrenal ax1s, but was not as potent a stressor as reserpine.

The effects of graded doses on adrenal welghts are extremely unusual and do not present the same dose-response effect as observod with reserpine and serum KS (TABLE XIII). The character of the pitultary welght vo. dose of reserpine Indicates a biphasic aotion of reserplne, firat stimlation, then Inhibition of the pitultary-adrenal axis (F1g. 7). The complementary nature of the relationship botwoon the ADW and pltultary welght rememphases this possiblo blpkasic eftect of rearpine on the p1tultary-adrenal axis. In oontrast to the biphasio offoct on this system, semum ind cates only a monophaso stimlating offoot by roserpine on the pltuitaryadronocortical axia. Thoso oonolusions aro valia if ono oonsiders an 1norease in adramal welgbt in contrast to dooreaso 1r p1tu1tary welght, as an Ind1cation of p1tu1tary-adranooort1- 
cal axis hyperfunction. The FADW and dry pltultary welght relationships in normaliy stressed rats would appear to conflrm such a corslusion (Fig. 6).

This effect could be explained if resarpine possessed both central and perlpheral effects. In support of such a possiblifty, Verdesca et al (196i) has shown trat 5-HT stlmilates adrenal function drectly, and increases corticosterold secretion. Since reserpine also induces peripheral reiease of 5-HT (Ersprner, 1961), a sedative dose could be envisaged as producing both an inblibition of the pituitary-adrenal axis centraliy, and a stimu latory effect peripherally on the adrenal cortex directly. Such a machanism could explain the apparent biphasic efíteots of sinRle graded doses of reserplne.

The reserpine control animals present during the restraint stress experiment, exhlbited unusually high adrenal dry welghts (TABLE VII). Tris efiect was not duplicated in this experiment. In several other experiments conducted in this laboratory, the adrenel dry welghts of animais receiving $1 \mathrm{mg} / \mathrm{kg}$ ot reserplne (32 days) were 10.0 $\mathrm{mg}$ per anlmal. This apparent discrepancy may be due to possible undue stress provided during the restraint stress oxperiment. The high serum KS levels of this experiment, as compared to the first experiment (TABLE X) also indicates that such increased stress conditions did exist.

After trirtyutwo days of dally admiristration of reserplre, no $\theta f e c t i v e$ stimulation of the pltultarywadrenal axis was apparent as compared with the effects of single graded doses (TABLES XII and XIII). What occurs between the first and thirtysecond day miaht be explained by three possiblilties: 
1. Reserpine acts as a nonspecifio stressor to which the animal eventually adapts (TABLE X).

2. Resarpine causes infibition by continued depletion of pltultary stores of ACTH (Kitay et al, 1959).

3. Reserpine produces a direct stimulatory effect on tho adrenal gland via peripheral serotonin (5-HT) $\dot{a}=$ pletion, to which the adrenal. elther adapts or eventually is itself ghrusted ry cronic stimia $\operatorname{tin} \sin _{0}$

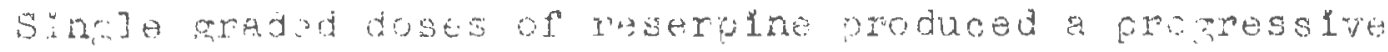

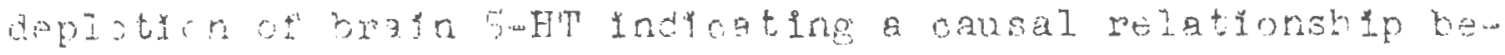

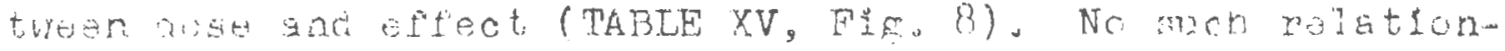

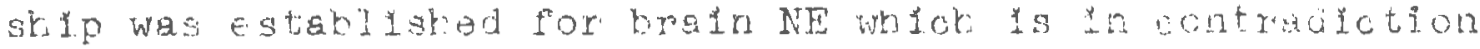
to Brodie and Shope $(1959)$ wro tatr establistad rquivalent derletion of both amines following a single dose of reserpine.

Since raserpinewnduced sedaticn appears to colrelate better with brain 5-HT as was okserved in previous axperiments, (TABIF, I) it is suggested trat reserpluewinduced sudation may ultimately be coused by brain 5-HT release.

Chronic administration of graded doses of reserpine indiw cated aomenkat of a reversal of 5-HT deplation wh the NE leveIs were lower than the first day. In fact, in almot rale of the assays conducted on andmals under ohrondc administration. of reserplno, no NE could be detected (TABLE XV).

As lndicated in th first experiment. (TABLE XI), 1 ma/kp

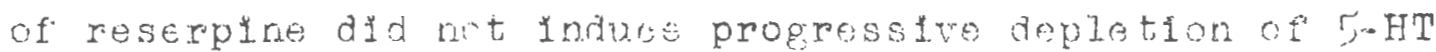
with time The $0.5 \mathrm{mg} / \mathrm{kg}$ dose of reserpine in this experiment, bowever, did appear to produce progresing depletion of $5-H T$ 
in contrast to the apparent inbibition of 5-HT depletion produced by $2 \mathrm{mg} / \mathrm{kg}$ (TABLE XV, F1g. 8).

The behavioral sequences Involved during this experiment clearly Indicate the ablilty of reserplate to produce some exc1tatory effects. It was observed that at about ralf way thrcugh the experiment, animals at all dose levels became extremely exc1table 24 hours following a dose of reserpine. - (Th1s was also indicated previously, TABLE I.). There was also evidence of extreme excitability in a group of animals receiving $2 \mathrm{mg} / \mathrm{kg}$ of reserpine. It is interesting to note that these animals evidenced high brain 5 HT levels and a low mean KS level of 18 ug/100 $\mathrm{ml}$ of serum. As indicated in TABLE IV, group III, although extremely excltable, they demonstrated KS levels below normal. Thus, stress could not be $1 \mathrm{mplicated}$ in producling such high 5-HT levels (FIg. 7).

One of the inftial objectives of this experiment was to attempt to separate rats resistant or sensitive to reserpine in order to obtain added information as to the mechanisms of reserplne tranquilization. However, due to the lack of suffi-. clent data, these objentives were not satisfied.

In relation to the ancillary hypotheses presented in the previous experiment, there are no clear Indications that chronic reserpine treatment produces chronic stimulatcry effects on the pituitary-adrenocortical axis.

The previous bypothesis that reserpine is inducing an increase in brain 5-HT syntbesis has also gained further support. The reversal of the degree of 5-HT depletion with increasing doses of reserpine does lend support to a posslble feedback meohantsm. 


\section{GENERAL DISCUSSION}

The basic assumption in this work has been that animals subfected to chronlc environmental stressors will respond differently to the actions of drugs and thus, alter their usual effects. This investigation has demonstrated the ut11Ity of studying the effects of drugs in animals under the Influence of chronic stress, especlally those which affect the central nervoug system.

At the onset of this investigation, several hypotheses were formulated whlch were then tested by subjecting reserpinized rats to chronic restraint stress. As has been noted, by necessity, two anclilary hypotheses were formulated and tested in order to elucldate the chronlc effects of reserpine on the brain NE and 5-HT and semum KS. In relation to these hypotheses, the following discussions w1ll be utilized in relating the results obtained to the mechanism of action of reserpine.

Neurochemical adaptation which appears to parallel behavioral adaptation has been characterized in normal and reserpinized rats. The increased behavioral activity assoclated with the initiation of restraint stress closely follows the increased brain 5-HT levels and decreased brain NE levels, both values returning to normal with behavioral adaptation (Fig. 6). Serum corticosterone levels aslde from being an index of adrenocortical activity, also appear to be an 
excellent index for behavioral adaptation.

The results from previous investigations indicate the validity of these observations. Thus Garattini et al (1960) found that electroshock produced an increase in brain $5-\mathrm{HT}$ levels in rats, whereas Maynert and clingman (1962) demonstrated depletion of brain NE in rats following a cold stress $\left(4^{\circ} \mathrm{C}\right)$.

The slgniflcance of these f'indings can be observed assuming that depletion of elther neurohumoral substance be interpreted as a decrease of neurotransmitter relegse assoclated with increased neuronal activity. If this assumption is correct, then during the initial phases of chronic stress, the activation of an NE dependent excitatory system in contrast to the 1nbibition of a 5-HT dependent system, could account for the behavioral activity observed.

Whether these neu rochemicals are actual neurotransmitters released from centrally located axons is st111 cnntroversial. Grundest (1957), in summarizing research from previous years, concludes that central nervous transmission is accomplished via neurochemicals. The evidence presented in favor of this arose from his inablilty to demonstrate electrically excltable central dendrites. Rothballer (1959) and Brodie and Shore (1957) also contend that changes in brain NE represent fluctuationg of excitatory activity initiated by an adrenerglo system. Brodie further postulates that $5-H T$ is released from a cholinerg1c mechanlsm during depressive activity.

In relation to these previous 1nvestigations, Whittaker (1961) and DeRobertis (1962) have isolated both NE and 5-HT from a centrifuged brain fration whlch contained nerve endings. 
Although these findings are not conclusive proof of the physlological roles of 5-HT and NE in the CNS, they do give encouragement to the interpretations presented in this investigation.

So far, these interpretations have been based on release mechanisms assoclated with increased neuronal activity. However, when one conslderes drug effects, dif'ferent interpretations can arise. The effects of drugs on neuronal activity can be looked at in several ways. First, a drug could stimulate a nerve which would then release a transmitter substance. Secondly, a drug could act by releasing the transmitter without stimulating the nerve directly. The end result in both cases would be the same. The second possibility would assume that the transmitter is acting as though its source was stimulated. However, this does not have to be, since many workers have shown that reserpine inhibits peripheral nervous transmission by exhausting NE from the ANS (Trendelenburg, 1961).

Bonnycastle et al (1962) observed an Increase in brain 5-HT levels in rats recelving sedatives such as phenobarbital and dilantin. On the other hand, Pletscher et al (1958) observed a similar increase with Ipronlazid, a CNS stimulant. Thus, once again these interpretations arrive at neurobumoral crossroads. Some light ma be shed on this problem through a recent paper by Schanberg and Glarman (1962). These workers found that reserpine increased the ratio of "Free/Bound" 5 HT in the brain, whereas Iproniazid decreased this ratio. They concluded that the increased brain 5-HT Levels produced by Iproniazid was an increase in the bound fraction, thus 
decreasing the total amount of $5-\mathrm{HT}$ accessible to postsynaptic sites. Here again, if we assume that the free amount of the neurohumoral agent is assoclated with increaseit neuronal activity, 5-HT does appear to be causaliy related to a depressant mechanism.

Brodie and his coworkers (1961) have provided good evidence that reserpine produces sedation by releasing serontonin from 1ts normally inactivo sites. They postulate that after relegse, 5mT then induces cNS depression at anme post ynaptic site. They havo also demonstrated that cold stress will prevent reserpine gedation concurrently with an inblbition of the normal 5m H depletion. Since NE remains depleted, they conclude that reserpine acts via 5-HT and not NE.

Chronic restraint stress was also found to prevent $5-\mathrm{HT}$ depletion by reserpine. However, in these axpeziments reserpinized stressed animals exhibited increased behavioral excitability concurrently with depleted brain NE, while brain 5-HT levels romained approximately normal (F1E.6). NE is thus associated again, with increased CNS excltation.

It should be pointed out again that strossod animals recolving reserpine demonstrate neurotic behavior after re. loase from restraint, though they appeared to be arnewhat sedated whlle undor restralnt. This observation is extremely Important for it cannot be concluded that this stress definitely inhibited reatrpinewirduced sedation. In other words, although these animals could have been under sodation, their roactions to change were violent. 
Reserpine, therefore, oppears to be stimulating both an Inhibltory and exc1tatory brain mechanism since RS causes only NE depletion which is apparently associated with an excitatory mechanism. This postulate is correct if the assumptions made previously are valid. Trendelenburg (196I) in a recent review article concerning the ANS, points out that reserpine produces 1ts peripheral effocts by complete exhaustion of peripheral NE stores. Thus, reserpine produces a chemlcal sympathectomy. Insofar as brain $\mathrm{NE}$ is concerned, it could be detected in only half of the assays after 32 days of reserpine administration (total NE depletion was about 90\%). Reserpine, therefore, may be producing exhausive depletion of the central sites of NE as well, thus producing a central hypersensitity sirilar to nerve postsynaptic hypersensitivity following denervation experiments. Such an apparent hypersensitity may be responsible for the behavioral excitation observed in reserpinized rats subjected to chronic restraint stress.

Past investigators have also demonstrated that reserpine causes a general release of several amines even including histamine in some species of animal (Burns and Shore, 1961). Reserpine, therefore appears to be producing a speciflc effect, sedation, through a nonspecific mechanism. Thus, reserpine should also induce depletion of brain 5-HT to eventual complete exhaustion if its action is a simple matter of preventing varlous amines from being bound. Reserpine, however, appears to induce an increased rate of 5-HT synthesis through a possible feedback mechanism. Such a mechanism was also suspected in 
relation to MAO Inhibitors by Costa et ai (1961).

Reserplne (I mg/kg) appears to deplete brain 5-HT levels equaliy throughout this investigation (Fig. 6). Since the degree of sedation was also unchanged in normsl arsimals throughout the 32 days, it would be loglcal to assume that the rate of $5 \mathrm{mT}$ synthesis and release were equivalent. This assumption can be made since the \% depletion of 5-HT and sedation are causally related to the dose of reserpine (Fig. B).

It was observed that $0.5 \mathrm{mg} / \mathrm{kg}$ of reserptne produced a progressive depletion of 5mH over 32 days (Fig. B). In contrast, $2 \mathrm{mg} / \mathrm{kg}$ produced an Inhibition of $5-\mathrm{HT}$ depletion; some animals exhibited levels above normal (TABLE XV). A possible 5-HT feedback mechanism lnvolving the f'ree to bound ratio of this amine may therefore be indicated. Thus, the rate of synthesis of 5-HT increased in some proportion to \% depletion. As indicated at the $2 \mathrm{mg} / \mathrm{kg}$ do se of reserpine, the rate of $5-\mathrm{HT}$ synthesis could be greater than its release.

A second proof of such a mechanism was evident in studying the recovery of brain 5-HT following one and thirty doses of reserpine ( $1 \mathrm{mg} / \mathrm{kg}$ ), (F1g. 3). The increased brain 5-HT levels, 24 hours following the last dose of reserpine, could be expla1ned on the basis of an increased rate of synthesis, since the 5-HT levels were below normal 8 hours after administratior of the duug. The rate of $N E$ syntinesis did not appear to change in any experiment conducted. The obvious accumulation of brain 5-HT could be explained on the basis of its inablitty to cross the bloodmbraln barrier (Erspamer, 1961). 
The behavioral sequences observed along with these increased brain 5-HT levels were also interesting. Throughout the latter half of this experiment, animals at all doses appeared extremely exc1table 24 hours following a previous dose of reserpine. The animals appeared to be hypersensitive to all external stimul1. These behavioral changes could very easily be explained if the brain 5-HT is not bound to an intracellular site. If this increased level of 5-HT represents a "Free" form, then 1t could be blocking 1ts own inhiblting effects in a manner similar to several cholinergic mechanisms (Brodle and Shore, 1957).

The interpretations of these results indicate that reserpine may be producing its sedative chronic effects by inducing a continuous releage of brain 5-HT ("Free"), which is main talned by an Increased rate of synthesis.

The fact that progresglve brain NE depletion was not paralleled by an increased degree of sedation supports the contention that reserpine is producing its effects via an increase in "Free" brain 5-HT levels.

The ablilty of reserpine to prevent adaptation was demonstrated beyond any reasonable doubt. The means by which it accomplished th1s, however, is a very debatable subject. From all of the demonstrated effects of reserpine, adaptation to chron1c RS is prevented by apparent starvation effects. It was observed (Tables IV-IX) that none of the organ welght changes assoclated with adaptation in normal animals were observable when an an 1mal recelving reserpine was also subjected to RS. The p1tultary-adrenal axis, however, appears 
to be somewhat operable since hlgh KS levels are malntalned even to the 32nd day, (TABLE X), (F1g. 6).

One interesting observation was made by Roserkrantz and Laferte (1960, and Verdesca et al (1961). These investigators have demonstrated that serotonin stimalates the adrenal cortex olrectly, inducing a release of corticosterolds. Since reserpine also depletes peripheral 5-HT in the rat (Erspamer, 1961), 1t is vary tempting to speculate that the 1ncreased dry weights of reserpinized animals (Fig. 4) were due to a direct action of 5-HT on the adrenal. This fact might al so explain the conflicting results of single graded doses of reserpine on adrenal dry weights (F1g. 7) and pitultary welghts.

Although all of this Information has been accumilated and scrutinized, we still cannot answer why a reserpinized animal does zot adapt to this stressor. Of the threo blochemical mochanlams assayed, (brain 5-HT and NE; semum KS), the only one which appears to be exhausted or below normel in reserpinized animals subjected to RS, is brain NE (FIf. 6). Since one would assoclate nonmadaptation with the lack of some physiologloal mechanism, It would be interesting to speculatio a relationship botween the apparent exhaustion of NE w1th non-adaptation. This reflection becomes even more interesting when one compares Cannon's work (1932) w1 th true sympathectomy, with Trendelenburg's remarks (1961) concerning a drug sympathectomy as produced by reserpine.

Necina and Krejei (196I), addad to this relationship by demonstrating that the usual peptic ulcers produced by reser. pinlzed animals subjected to cold stress ( 6 hours), could be 
completely Inhlbited by administering dihydroxyphenylalanine (DOPA), a pracursor of NE. They also observed that the usual $50 \%$ mortality in resarpinized animals subjected to colo stress could also be prevented by DOPA.

In relation to this investigation, on the $32 \mathrm{nd}$ day, brain NE was barely detectable. This, of course, is no indication of what occurs peripheral1z. However, after 32 doses of reserpine, the usual splnal reflexes assoclated with sacriflcs were completely absent. This very dramatic effect may ind 1cate the loss of all ANS reflex ability.

In view of this data concerning NE and adaptation to stress, It is sugeseted that NE may play an important role at the tissue level, in enabling animals to adapt to all stresses.

Initially it was mentionod that drugs potentially possoss the ablifty to affect several segments of the pltultary adrenom cortioal axis (Fig. I). Chronlc restralnt stress by its very nature stimiates the peripheral side, activating the complete oha1n of command 11liciting oorticosterone rolease into the general clrculation at the opposite side. Reserpine on the other hand, acutely Induoed corticosterone release. Where reserpine acts, however, is not so clear.

The \% depletion of brain 5-HT appears to be somewhat couse.ily celated to increased serum KS levels. Westermann et al (1962) postulated that reserpine induces serum KS release by increasing the "Free" brain 5-HT levela in the IImblc System of the brain, which in turn induces ACTH release, possibly via the CRF of the hypothalamus. If the is proposal is correct, then reserpine should either induce a similar increase 
In serum KS levels a ter 32 doses as after a single dose, or should produce inhibltion of the pitultaryadrenocortical axis by exhaustion.

In contrast, nelther of the above possiblilties were clearly present in tris investigation. Serum KS levela were neither increased nor decreased following chronic administration of reserpine. Since chronic brain 5-HT depletion was not causually related to Increased semukS levels, the hypothes is that ACTH is dependent on "Free" brain 5wT levels, was not supported in this invastigation.

That the divergent effects produced by reserpine on pituiw tary-adrenocortical function (serum KS levels vs. pitultaryadrenal welghts) could be due to a possible direct effect of peripheral 5uH on the adrenal cortex, is certainly 1mmaginative. If such an effect were proved, much of the contradictory results obtalned with reserpine could be rectifled.

Thus, where reserpine acts in producing its effects on the pitultaryuadrenocortical axis, atill remains a mystery.

Concerning these two hypotheses, the following finel statements are presented:

IA. Reserpine does not appes to produce chronio pltultaryadrenocortical stimulation as ind1... cated by semum KS levels. However, Indirect data dies indicate that reserpine may possess a bibasic effect on this system which could be eclipsing the time ploture.

IIA. Reserpine-1nduced brain 5-HT ralease appears to correlate better with sedation than does NE. 
Proof that raserpine is inducing 5-HT synthes 1s has boen presented. Whether such a mechanism can explain the mechaniam of action of reserpine awalts more persuasive evidence correlating reserpine sedation and brain 5-HT levels. 


\section{SUMMARY AND CONCLUSIONS}

The study of the influence of chronic stress in animals recelving a drug, especially one which modifles CNS activity, was proven to be a very worth while venture. Aslde from addIng to the information concerning the action of a drug, the Influence of the ding on chronic stress can also ald in the elucidation of basic endocrine mechanisms concerning the stress. In view of the experiments conducted in this investigation and their interpretations, the conclusions of these efforts are now presented.

1. Animals subjected to a chronic forced restraint stress adapted well in terms of Selyo's General Adaptive Syndrome. Pitultary-adrenocortical adaptation may involve an increase in the efficiency of this system.

2. Behavioral adaptation associated with restraint stress was observed to be related to brain neurohumoral levels. Thus, hyperexc1tabli1ty was assoclated with increased brain 5-HT levels and decreased brain NE levels.

3. Reserpine ( $1 \mathrm{mg} / \mathrm{kg}$ ) prevented anlmals from adapting to the chronic stressor of forced restraint.

4. It was postulated that reserpine presentad adaptation by producing a chemical sympathectomy. These results suggest the possible signiflcance of the sympathetic division of the ANS and adrenal catechol amines in enabling animals to adapt to chronic stress. 
5. Reserpinized animals reversed the bohavioral adaptation demonstrated by normal animals. The progressive increase in behavioral hypersensitivity observed was assoclated with the progressive depletion of brain NE levels whereas brain 5-HT levels remained normal throughout this perlod of activity.

6. Evidence was presented that reserpine Induced an increased rate of 5-HT synthesis with no slmilar effect on brain NE. The supranormal levels of brain 5-HT at higher chronic doses of reserpine and observed in brain 5-HT recovery studies, Indiogtes the existenoe of a possible serotinin feedback mechanism involving the bound and free concentrations of this amine. These high serotonin levels were also assoclated with behavioral hyperactivity. 


\section{IITERATURE CITED}

Albert, So: Changes in adrenal function during the alarm reaction. Proc. Exptil. B10I. \& Med. 51: 212, 1942

Be1n, H. J.: Effects of reserpine on the functional atrata of the nervous system. In: Psychotrop1c drugs, ed. by S. Garettinl and $V$. Ghett1, pp. 325-331. Elsevier Press, Amsterdam, 1957

Bertler, A.: Effect of reserpine on the storage of catechol amines in brain and othor tissue. Acta physiol. scand. 51: 75,1961

Bonnjcastle, D. D., Bonnjcastle, M. F , and Anderson, E. G.: The effect of a number of central depressant drugs upon brain 5-hydroxytrytamine levelg in the rat. J. Pharmacol. \& Expl11. Therap. 135: 17, 1962

Brodie, B. B., Flnger, K. F., Orlans, F. B., Quinn, G. P. and Sulser, F.: Evidence that tranquilizing action of reserpino is assoolated with change in brain serotonin and not brain norepinephrine. J. Pharmacol. \&e Exptil. Therap. 129: 250,1960

Brodie, B. B., shore, P. A.: A concept for a role or Serotonin and noreplnephrine as chemical mediators in the brain. N. Y. Acad. Sc1. 66: 631, 1957

Brodle, B. B., Sulser, F. and Costa, E.: Psychotherapeutlo Drugs. Ann. Rev. Med. 12: 349, 1961

Burns, J. J. and Shore, P. A.: Blochemical effects of drugs. Ann. Rev. Pharmacol. I: 79, 1961

Cannon, W. B.: The wisdom of the body. W. W. Norton \& Co. Inc., N. Y., 1932

Carlsson, A., Lindquivist, Magnusson, M. and Waldeok, B. On the presence of 3 -hydroxytryptamine in brain, Science 127: 471,1958

Carlsson, A., Rosengren, E., Bretler, A. and N1Isson, J.: Effect of reserpine on the metabolism of catochol amines. In: Psychotroplc Drugs, od. by S. Garattinl and V. Ghott1, pp. 363-372. Elsevier Press, Amsterdam. 1957 
Christian, J. J.: Reserpine suppression of denisty dependent adrenal hypertrophy and reproductive hypoendocrinism. Am. J. Phys 101. 1937: 353, 1956

Costa, E., Psche1dt, G. B., Van Meter, W. G, and Himw1ch, H. E.: Brain concentrations of blogenic amines and EEG patterns of rabbits. J. Pharmacol. \& Expt'l. Therap. 130: 81,1960

D'Angelo, S., Gcrdon, A. S. and Charipper, H. A.: A differential response of the rodent adrenal gland to acute starvation. Proc. Exptil. B1ol. \& Med. 6E: 527, 1948

De Robertis, E., Pellegrinn de Trald1, Rodriguez de Lores Arnalz Salganifofi, L.: Crolinergic and Non cholinergic nerve endings in rat brain, J. Neurochem. 2: 21, 1962

Domino, E. F.: Sites of some central nervous system depressants. Ann. Rev. Pharmaonl. 2: 215, 1962

Erspamer, V.: Recent research in the fleld of 5-hydroxytryptamine and related indolalklamines. In: Progress in Dras Research, pp. 15I-368 Ed. E. Jucker, Birkhauser AG., BaseI, I96I

Garattin1, S., Kato, R. and Valzell1, L.: Blochemical effects induced by electrochock. Psychiat. et Neurol. 140: 190, 1960

Gaunt, R., Renz1, A. A., Antonchak, V., Milier, G. J. and G1lman, M.: Endocrine aspects of the pharmacology of reserpine. Ann. N. Y. Acad. Sc1. 59:22, 1954

Giarman, N. J. and Schanberg, S.: The intracellular distribution of 5-bydroxytryptamine (HT; serotonin) in the rat's brain. J. Blochem. Pharmacol. 2: 301, 1959

Grundfest, $\mathrm{H}_{\text {: : }}$ General problems of drug actions on bioelectric Phonomena. Ann. N. Y. Acad. Sc1. 66:537, 195?

Gulliemin, R.: Centrally acting drugs and pltultaryadrenal responses to stress. In: Brain Mechanisms and Drug Action, Ed. W. S. Fields, C. C. Thomas, Springfield, 1957

Gulliemin, R., Clayton, G. W., Smith, J. D. ard Libscomb, H. S.: Measurement of free corticosteroids in rat plasma: physlological validation of a method. Endocrinology 63: 349 , $195 \overline{8}$

Guillemin, R., Clayton, G. Wo, Libscomb, H. S. and Smith, D.: Fluorometric measurement of rat plasma and adpenal corti costerone concentration. J. Lab. \& Clin. Med. 53: 833, 1959 
Harris, G. W.: Neural control of the pitultary gland, Edward Arnold, Ltd., London, 1955

Herbst, A. I., Yates, F. E., Glenste1n, D. W. G. and Urqeshart, J.: Variation in hepatic inactivation of corticosterone with changes in food intake: an explanation of impared corticosterold metabolism following noxious stimil. Endocrinology 67: 222, 1960

Holzbauer, M. and Vogt, M.: Depression by reserpine of the noreadrenalin concentration in the hypothalamis of the cat. J. Neurochem. 1: 8, 1956

Jacobson, E.: Effect of psychotroplc drugs under psychic stress. In: Psychotrople Drugs, ed. S. Garattini and V. Ghett1, pp. 119-124. Elsevler Press, Amsterdam, 1957

Kltay, J. I., Holub, D. A and Jaller, J.W.: Inblbition of p1tuitary ACTH after administration of reserpine and epinephrine. Endocrinology 65: 548, 1959

Mahouz, M. and Ezz, E. A.: The effect of reserpine and chlorpromazine on the response of the rat to acute stress. J. Pharmaco 1. Expt'1. Therap. 123: 39, 1958

Malckel, R. P., Westermann, E. O. and Brodle, B. B. : Effects of reserpine and cold exposure on p1tultary-adrenocortical function in rats. J. Pharmacol. \& Expt'l. Therap. 134: 167,1961

Maynert, E. W. and Klingman, G. I.: Tolerance to morphine. I. Effects on catecholamines in the brain and adrenal glands. J. Pharmacol. \& Expt'1. Therap. 135: 285, 1962

Mead, J.A. R, and Flnger, K. F.: A single extraction me tho d for the determination of both norepinephrine and serotonin in brain. J. Blochem. Pharmacol. 6: 52, 1961

Nontanar 1, R. and Stockham, M. A.: Effects of single and repeated doses of reserpine on the secretion of adrenocort 1 cotroph1c hormone. Br1t. J. Pharmaco 1. 18: 337, 1962

Mueller, J. M., Schlittler, E., and BeIn, H. J.: Reserpin, der sedative Wirkstof aus Rauwolfla serpentia Benth. Exper1ent1a 8 : 338,1952

Necina, J. and Krejcl, I. On the role or serotonin and catecholamines in relation to some effects of reserpine. Abstr. Ist Int. Pharmacol. Meet., 35, Stockholm, 1961

Passonen, M. K.: The role of Noreadrenaline and 5-hydroxytryptamine in the central actions of rauwolfia alkalolds and benzoquinolizine derlvatives. Blochem. Pharmacol. 5 : 389,1961

Pletscher, A., Besendorf, H. and Gey, K. F.: Depression of noreplnephrine and 5 wydroxytryptamine in the brain by benzoquinolizine derlvatives. Sclence 129: 84.4, 1959 
Pletscher, A., Shore, P. A. and Brodle, B. B.: Serotorin as a mediator or reserpine action in the brain. J. Pharmacol. \& Expt'1. Ther ap. 116: 84, 1956

Plummer, A. J., Earl, A., Schnelder, J.A., Trapold, J. and Barrett, W.: Pharmacology of rauwolfia alkalnids incluaing reserpine. Ann. N. Y, Acad. Sc1. 59: 8, 19:4

Renaud, S.: Improved restralnt-technique for producing stress and cardiac necrosis in ratg. J. Appl. Physiol. 14: 568, 1959

Revizin, A. M., Spector, S. and Costa, E.: Relationship botween reserpine-inchced facilitation of evoked potentials in tre limbic system aid change in $k_{i}$ ir serotonin levels. Abstr. Ist. Prarmacol. Meetitis pp. 39, Stockbolm, 1961

Rothballer, A. B.: The effects of catecholamines on the central nervous system. In: Symposium on Catecholamines. ed. by 0 . Krayer, pp. 494, The Wililams and Wiitins Co., Baltimore, Ma., 1959

Rozenkrantz, H. and Lafer te, R. O.: Further observations on the relationship between serotonin and the adrenal. Endocrinology. 66: 832, 1960

Saliaran, M. and Vogt, M.: Depletion of pltultary corticotrophin by reserpine and by a nitrogen mustard. Brit. J. Pharmacol. 15: 165, 1960

Saffaran, M.: Mechanisms of adrenocortical control. Brit. Med. Bul1. 18: 122, 1962

Sayers, G.: Adrenal cortex ard homeostasis. Physiol. Rev. 30: 241,1950

Schanberg, S. M. and Glarman, W. J.: Drug Induced al terations in the subcellular distribution of 5-HT in rat's brain. Blochem. Pharmaco1. 11: 187, 1962

Scblitler, E., Dorfman, L., Macphlilamy, H. B., Furlenmeler, A., Heubner, C. F., Lucas, R., Mueller, J. M., Schיn+rzer, R. and Andre, A. F.: Chemistry of rauiolifia alkaloids, including reserplne. Ann. N. Y. Acad. Sc1. 59: 1, 1954

Selye, H.: Stress. Acta Inc., Montreal, 1950

Smlth, P. E.: The disabilities caused by hypophysectomy and thelr repalr. J. Amer. Med. Assoo. 08: 158, 1927

Trendelenburg, P.: Pharmacology of autonomí earglia. Ann. Rev. Pharmacol. I: 219, 1961 
Turner, R. F. and Tinerity, J. C.: Cytological and welght changes in pitultary gland of severely stressed rats. Proo. Expti1. B101. \& Med. 91: 420, 1956

Verdesca, A. S., Westerman, C. O., Crampton, R. S., Black, W. C., Nedelfkov1c, R. I. and Hilton, J.C.: Direct adrenocortical stimulatory effect of sarotonin. Am. J. Phys101. 201: 1065, 1961

Voet, M.: The control of the secretion of corticosterolds. In: The Blosynthes $1 \mathrm{~s}$ and Secretion of Adrenocorticosterolds, Ed. by F. Clark and J. K. Grant, pp. 96-110, University Press, Cambridge, 1960

We1]-Malherbe, H., Posner, H. S and Bowles, G. R.: Changes in the concentrations and intracellular distribution of brain catecholaminos: the effects of reserpine Buphenyil sopropylhyarazine, pyrogal101 and 3,4 , dihydroxyphenlyalanine, alone and in combination. J. Pharmacol. \& Expt'i. Therep. 132: 278, 1961

Welskrantz, L.: Reserpine and behavioral nonmeactivity. In: Psychotroplc Drugs, Ed. S. Garatinl and V. Ghett1, pp. 6772. Elsevier Press Amsterdam, 1957

Wells, H., Blegs, F. N. and Munson, P. L.: The Inbibltory effects of reserpine on ACTH secretion in response to stress ful1 stimul1. Endocrinology, 59:571, 1956

Westermann, E, O., Malckel, R. P. and Brodle, B. B.: On the mochanism of pltultary-adrenal stimulation by reserpine. J. Pharmacol. Expti1. Therap. 138: 208, 1962

Whituker, V. P.: The subcellular localization of transmitter substances in the central nervous system. Blochem. Pharm mecol. 5: 392,1961

Zenker, N. and Bernste1n, D. E.: The estimation of small amounts of corticosterone in rat plasma. J. Blol. Chem. E3I: 695, 1958 
VII'A

John Adam Rosecrans was born July 30. 1935. In Brooklyn, New York. He recelved his B. S. degree in Phamacy from $S t$. John's Unlversity in June, 1957, and proceeded to the Univerw sity of Rhode Igland as a graduate assistant in soptember, 1957. He recelved his M. S. degree in Pharmacology in June, 1960. Wh1le conduct1ng research in pharmacology with several plant drugs.

In 1961 while contimulag study for the Ph. D. degree, be was appointed as Instructor in Pharmacology for orie year after which he recelved a predoctoral fellowship from the National Institutog of Mental Hadth. He completed the rew quirements for the Ph. D. In Pharmacology in February, 1963.

He has two publications concerning the pharmaoology of various plant extracts. He is also a member of the Rho Chi and Slgma XI honor socleties.

He married Norma J. Pareti in 1958 and has two childron: a daughter, Jane, and a son, John. 